\title{
Oviposition and egg mass morphology in barred frogs (Anura: Myobatrachidae: Mixophyes Günther, 1864), its phylogenetic significance and implications for conservation
}

\section{management.}

\section{Ross Knowles', Karen Thumm², Michael Mahony', Harry Hines ${ }^{3 *}$, David Newell ${ }^{4}$ and Michael Cunningham ${ }^{5,6}$}

'Department of Biological Sciences, The University of Newcastle, Callaghan NSW 2308.

${ }^{2}$ Office of Environment and Heritage, Newcastle, NSW 2302.

${ }^{3}$ Ecological Assessment Unit, Queensland Parks and Wildlife Service, Department of National Parks, Recreation, Sport and Racing, GPO Box 2454, Brisbane, Qld 400I.* Corresponding author email: Harry.Hines@nprsr.qld.gov.au

${ }^{4}$ School of Environment, Science and Engineering, Southern Cross University, PO Box I57, Lismore NSW 2480.

${ }^{5}$ South African Institute for Aquatic Biodiversity, Private Bag 1015, Grahamstown, 6I40, South Africa.

${ }^{6}$ Department of Genetics, University of Pretoria, Private Bag X20, Hatfield 0028, Pretoria, South Africa.

Several species of the Australo-Papuan genus Mixophyes (barred frogs) have declined markedly and are now considered threatened. During field investigations into the possible causes of declines, we observed oviposition and numerous egg masses $(700+)$ of the four species from southeast Australia. From these and published observations there are two markedly different ovipositional processes within Mixophyes. In M. coggeri, M. fasciolatus and M. iteratus eggs are laid in water then deposited terrestrially, propelled from the foot of the floating female onto a near-vertical or overhanging stream bank (Ovipositional Process I). In M. balbus and M. fleayi eggs are deposited aquatically in the shallow riffle zones of small streams, either into a rounded nest depression in the substrate (Ovipositional Process $2 \mathrm{~A}$ ), or occasionally directly onto bedrock (Ovipositional Process 2B). These observations of ovipositing and egg masses show that there are three reproductive modes in the genus: mode 2 - eggs and exotrophic tadpoles in lotic water (M. fleayi), mode 4 - eggs and early larval stages in constructed basins, exotrophic tadpoles in streams subsequent to flooding - (M. balbus and M. fleayi), and mode 18 (terrestrial eggs above water, exotrophic hatchlings move to water (M. carbinensis, M. coggeri, M. fasciolatus, M. iteratus and M. schevilli). Mixophyes fasciolatus was the only species to use both lentic as well as lotic waters for larval development. For the Australian species amplexus was axillary, occasionally shifting during the process of oviposition to inguinal. Amplexus for the New Guinean M. hihihorlo, is unknown, as is the ovipositional process and reproductive mode. The phylogenetic significance of our observations is that Mixophyes species have non-foamy egg masses, which accords with their recent placement in the family Myobatrachidae. However, no other members of this family show either of the described processes of oviposition, and furthermore we observed amplexus in Mixophyes to be axillary whereas all other reports for myobatrachids are of inguinal amplexus. Our findings have consequences for management of the habitat of barred frogs, three of which are considered threatened. The construction of creek crossings (for vehicles, bikes, horse riding, pedestrians) in riffle zones, the trampling of creek banks by cattle, horses, pigs and humans and changes to the hydrology of creeks by damming or regulating flows that alter the connection between hydrology and stream bank structures, are all likely to have a negative impact on reproductive success.

Key words: natural history, threatened, declining, amphibian, breeding, reproduction, management, spawn

DOI: http://dx.doi.org//0.7882/AZ.2014.040

\section{Introduction}

Barred frogs (Mixophyes) are moderate to large grounddwelling amphibians of the family Myobatrachidae (sensu Frost et al. 2006). Seven species occur in eastern Australia and an eighth species, M. hihihorlo, is known only from the type collection from Namosado in the Southern Highlands of Papua New Guinea (Donnellan et al. 1990; Mahony et al. 2006; Menzies 2006). The Australian species breed in streams in forests of the coastal plains 
and adjacent ranges of the mesic east coast (Gillespie and Hines 1999; Hines, Mahony and McDonald 1999, Meyer, Hines and Hero 2001; Hoskin and Hero 2008) and M. fasciolatus also breed in lentic waters (Mahony 1993; Hines, Mahony and McDonald 1999; Lemckert 1999; Meyer, Hines and Hero 2001; Parris 2002). Three of the four south-eastern Australian species have suffered serious population declines and are listed as threatened in the IUCN Redlist (IUCN 2012), and under state and federal legislation (Gillespie and Hines 1999; Hines, Mahony and McDonald 1999; Hero et al. 2007) (Table 1). Basic life history information is important for understanding and ameliorating threats to species. Despite the extensive distribution of Australian Mixophyes, and conservation concern for three species, published information on their breeding biology is limited and at times conflicting. Here we describe different oviposition behaviours and resulting form of egg masses among the four Mixophyes species from south-eastern Australia and compare this to what is known for other members of the genus. Shared reproductive characters are examined in the context of systematic relationships within Mixophyes and these inform debate over the familial placement of this genus.

Until the late 1960s Mixophyes was considered a single species, M. fasciolatus (e.g. Moore 1961). Straughan (1968) revised the genus, describing M. balbus and M. iteratus, raising M. fasciolatus schevilli to species status and redefining M. fasciolatus. The only information we have found on oviposition or egg masses of Mixophyes prior to Straughan's (1968) revision, was in Straughan's (1966) unpublished $\mathrm{PhD}$ thesis, for M. fasciolatus (sensu stricto Straughan 1968). The site of egg deposition was reported for M. fleayi when this species was described in 1987 (Corben and Ingram, 1987). Donnellan, Mahony and Davies (1990) described M. hihihorlo, the only known member of the genus from Papua New Guinea, and the M. schevilli complex was reviewed by Mahony et al. (2006) who described two new species, M. carbinensis and M. coggeri. These latter two taxonomic works did not include information on oviposition or egg masses for the respective species. In the following section, we provide a summary of published accounts (roughly in chronological order) of oviposition and the form of egg masses of Mixophyes. The unpublished $\mathrm{PhD}$ of Straughan (1966 unpubl.) was included as it provided information not presented in Straughan's subsequent (1968) revision of the genus Mixophyes.

Early accounts of Mixophyes provide scant information on breeding with Fletcher (1889) surmising that they breed in summer, amplexus is axillary and oviposition is "in water in the ordinary manner". The first description of the egg mass of Mixophyes is that of Straughan (1966 unpubl., p. 26) and refers to M. fasciolatus sensu stricto: "Amplexus is axillary and is initiated out of water at the calling site of males. Only one clasped pair was seen to enter water and this was on disturbance. Egg masses are deposited in loose detritus along banks (plate 5), and contain 1400 to 2000 eggs. Embryo development takes place in the litter and is summarised in fig. 2 . When larvae hatch they are washed by rain or flood into the water body where development is completed." Straughan's (1966 unpubl.) plate 5 is a photograph of

Table I. The list of Mixophyes species, their common names, authority, conservation status (IUCN 20I2) and legislative status (QId - Queensland Nature Conservation Act 1992, NSW - New South Wales Threatened Species Conservation Act 1995, Vic - Victorian Flora and Fauna Guarantee Act 1988, Fed - Commonwealth Environment Protection and Biodiversity Conservation Act 1999). Codes for conservation and legislative conservation status: EN = endangered, $\mathbf{L C}=$ listed as least concern or not considered threatened, NA = not applicable as the species does not occur in that jurisdiction, $\mathrm{VU}=$ vulnerable.

\begin{tabular}{|c|c|c|c|c|c|c|c|}
\hline \multirow[b]{2}{*}{ Scientific name } & \multirow[b]{2}{*}{ Common names } & \multirow[b]{2}{*}{ Authority } & \multirow{2}{*}{$\begin{array}{l}\text { Conservation } \\
\text { status }\end{array}$} & \multicolumn{4}{|c|}{ Legislative status } \\
\hline & & & & Qld & NSW & Vic & Fed \\
\hline Mixophyes balbus & $\begin{array}{l}\text { Southern Barred Frog } \\
\text { Silver-eyed Barred Frog } \\
\text { Stuttering Frog }\end{array}$ & Straughan, 1968 & $\mathrm{VU} C \mathrm{CI}+2 \mathrm{a}(\mathrm{i})$ & NA & EN & VU & VU \\
\hline Mixophyes carbinensis & Carbine Barred Frog & $\begin{array}{l}\text { Mahony, Donnellan, } \\
\text { Richards \& McDonald, } \\
2006\end{array}$ & LC & LC & NA & NA & LC \\
\hline Mixophyes coggeri & Mottled Barred Frog & $\begin{array}{l}\text { Mahony, Donnellan, } \\
\text { Richards \& McDonald, } \\
2006\end{array}$ & LC & LC & NA & NA & LC \\
\hline Mixophyes fasciolatus & $\begin{array}{l}\text { Great Barred Frog } \\
\text { Great Barred River-frog }\end{array}$ & Günther, 1864 & LC & LC & LC & NA & LC \\
\hline Mixophyes fleayi & Fleay's Barred Frog & $\begin{array}{l}\text { Corben and Ingram, } \\
1987\end{array}$ & EN B2ab(ii,iii,iv,v) & EN & EN & NA & EN \\
\hline Mixophyes hihihorlo & & $\begin{array}{l}\text { Donnellan, Mahony } \\
\text { and Davies } 1990\end{array}$ & Data deficient & NA & NA & NA & NA \\
\hline Mixophyes iteratus & $\begin{array}{l}\text { Giant Barred Frog } \\
\text { Giant Barred River-frog }\end{array}$ & Straughan, 1968 & EN B2ab(ii,iii,iv,v) & EN & EN & NA & EN \\
\hline Mixophyes schevilli & Northern Barred Frog & Loveridge, 1933 & LC & LC & NA & NA & LC \\
\hline
\end{tabular}


an M. fasciolatus egg mass in-situ, sitting upon leaf litter. His figure 2 illustrates embryonic development over time and shows diameter (most likely capsule) increases from $2.1 \mathrm{~mm}$ at stage 12 to $3.6 \mathrm{~mm}$ at stage 25 (stages as per Gosner 1960, sample size not stated).

It appears likely that Straughan's observations were the basis for the first published account of the life history of Mixophyes, by Martin (1967, p. 179): “...Mixophyes fasciolatus, is characterized, at least in some situations by terrestrial oviposition of non-foamy egg-masses and subsequent aquatic larval life. Breeding occurs along fast-flowing streams, and the tadpole is of the mountainstream type. Male frogs call from depressions in leaf litter up to three metres from the water's edge. Amplexing pairs have been observed in similar sites and also in the water or on rocks near the water. Egg-masses have been collected in litter on the bank of a dry gully which becomes flooded after rain (Straughan, personal communication). No information is available on the length of time for which the eggs can remain viable in such sites prior to flooding."

For M. balbus (Point Lookout, NSW), Watson and Martin (1973, p. 37) describe eggs as being pigmented with ovidiameter about $2.8 \mathrm{~mm}$, laid in clusters on rocks or gravel near the edge of flowing streams. It is not clear whether the eggs they observed were within the stream or laid terrestrially. However, they later state the life histories of M. balbus and M. fasciolatus appear to be essentially identical (quoting Martin 1967), inferring that the eggs of M. balbus are terrestrial.

The view that Mixophyes have terrestrial eggs and aquatic larvae is held by Heyer and Liem (1976), Barker and Grigg (1977), Tyler (1985, 1994), Robinson (1993), Barker, Grigg and Tyler (1995) and Hoser (1989) with the latter adding that M. balbus lay their eggs in vegetation adjacent to streams. Corben and Ingram 1987) observed eggs of M. fleayi under a rock about $30 \mathrm{~cm}$ from water and attended by an adult.

More detailed accounts of oviposition and or egg masses appeared from the mid-1990s. Marantelli (1995) describes the egg mass from captive M. fasciolatus. A pair in a small terrarium comprising two terrestrial areas separated by water up to $18 \mathrm{~cm}$ deep laid 1100 eggs scattered all over the tank. Some eggs were in water, others above water attached to rocks or on the sides of the pond, through leaf litter and on the walls of the tank up to a height of $40 \mathrm{~cm}$. Oviposition was not observed but he postulated that fertilised eggs are thrown at the surfaces to which they wish them to adhere. Many eggs became desiccated, with only those in water and to about $50 \mathrm{~mm}$ above water remaining viable, hatching after 11-18 days (temperature $\left.16-21^{\circ} \mathrm{C}\right)$. Hatching tadpoles were observed to wriggle violently, seemingly to rupture the capsule, and to assist them in reaching the water.

In February 1998 one of the current authors (HH) gave a presentation at the annual general meeting of the Australian Society of Herpetologists at Yungaburra in Queensland, on oviposition in the four species of Mixophyes species from south-eastern Australia (Knowles et al. 1998 unpubl.). This presentation described two modes of oviposition among these species. Mixophyes balbus and
M. fleayi constructed a 'nest' in the shallow running water, with eggs deposited in a shallow excavation in the stream bed or pasted directly onto bed rock. Mixophyes fasciolatus and M. iteratus deposited their eggs out of water, under overhanging banks or on steep banks, of larger pools. Subsequently, information from this presentation is cited in the literature as "Knowles et al. (1998)", "Knowles et al. (in prep.)", or as personal communications from one or more of the current authors. The data and observations underlying these sources of information are detailed in the results section below.

Lewis (2000) provides the first published account of egg laying in M. balbus. A pair was observed to create eight nest depressions in the gravel and detritus substrate in shallow water (up to $4 \mathrm{~cm}$ deep) of an upland second order stream. Eggs were laid in four main clumps (and a few small scattered clumps), with an estimated total of 250 eggs. Nest depressions averaged $10 \mathrm{~cm}$ in diameter. Nests were evenly spaced over an 80 x $50 \mathrm{~cm}$ area, averaging $15-20 \mathrm{~cm}$ distance between each depression. Amplexus was observed between 02:20 hours and 09:10 hours with the eggs most likely laid during daylight hours. A colour photograph of the pair in amplexus is provided, but the egg mass is not illustrated.

A photograph of the breeding habitat of M. fleayi at Lamington Plateau and of an egg mass of M. fasciolatus on an undercut bank in the D'Aguilar Range, both southeast Qld is provided by Meyer, Hines and Hero (2001).

For the south-eastern Australia species of Mixophyes, Anstis $(2002,2013)$ describes the breeding sites, embryos and oviposition based largely on the observations of Knowles et al. (1998 unpubl.) and Lewis (2000). In addition she presents egg mass counts of three female M. balbus held captive from the onset of amplexus: 647 and 642 (Olney State Forest) and 1019 eggs (Point Lookout). She shows photographs of M. balbus eggs (labelled Gloucester Tops but from Sharpes Ck, Barrington Tops NP, NENSW, Table 2), M. fasciolatus ovipositing and egg masses (Bat Cave Ck, Nightcap NP, NENSW, Table 2, Figure 2), a pair of M. fleayi in a nest depression with eggs (Gap Ck West, Main Range NP, SEQ, Table 2), and eggs (Yabbra Ck, Yabbra NP, NENSW, Table 2) and eggs of M. iteratus (Desert Ck, Washpool NP, NENSW, Table 2, Figure 11).

Banks et al. (2003) report on spawning of M. fasciolatus in captivity over the period 1998-2000. During this time they observed oviposition once and egg masses on 13 occasions. Eggs were deposited on rocks and branches/ bark at the water's edge. More specific details are provided for the first three egg masses observed. On 13 Apr 1998 approximately 500 eggs were laid in two clumps on a flat water-soaked piece of timber overhanging the water, approximately $10 \mathrm{~cm}$ above the surface of the water. A small number of eggs was within a narrow cavity on wet rocks under the timber and some were in water. Eggs hatched after eight days with embryos dropping directly into the water. The eggs laid in water failed to hatch. Subsequent egg masses, laid on 24 Sep 1998 and 26 Oct 1998 were similar but with a smaller (approximately 300) number of eggs. During the third laying, oviposition was 
Table 2. Locations where oviposition or egg masses of Mixophyes species were observed. Latitude and Longitude are rounded to the nearest minute (datum is GDA94). Alt is the mean altitude $(\mathrm{m})$ of the stream section (n.b. some stream sections surveyed were in excess of $1000 \mathrm{~m}$ long). Abbreviations used in Locality are: $\mathrm{Ck}=$ creek, trib. $=$ tributary, $\mathrm{R}$. = river, MENSW = mid-east New South Wales, NENSW = northeast New South Wales, SEQ = southeast Queensland, NP = National Park, SF = State Forest. Species abbreviations used in Oviposition and Egg masses are Mba = M. balbus, $\mathrm{Mfa}=\mathrm{M}$. fasciolatus, $\mathbf{M f l}=\mathrm{M}$. fleayi, Mit = M. iteratus. Atypical egg masses (i.e. those with very low numbers of eggs or with eggs in scattered or diffuse clumps or obviously contained multiple clutches of eggs) are excluded.

\begin{tabular}{|c|c|c|c|c|c|}
\hline $\begin{array}{l}\text { Latitude \& } \\
\text { Longitude }\end{array}$ & $\begin{array}{l}\text { Stream } \\
\text { order }\end{array}$ & Alt & Locality & Oviposition & Egg masses \\
\hline $24^{\circ} 22^{\prime} \mathrm{S} 151^{\circ} 00^{\prime} \mathrm{E}$ & । & 840 & $\begin{array}{l}\text { Kroombit Ck north branch, Kroombit Tops } \\
\text { NP, SEQ }\end{array}$ & & Mfa $\times 2$ \\
\hline $24^{\circ} 23^{\prime} \mathrm{S} 151^{\circ} \mathrm{O} I^{\prime} \mathrm{E}$ & 2 & 800 & $\begin{array}{l}\text { Kroombit Ck south branch, Kroombit Tops } \\
\text { NP, SEQ }\end{array}$ & & $M f a \times I$ \\
\hline $26^{\circ} 43^{\prime} \mathrm{S} 152^{\circ} 34^{\prime} \mathrm{E}$ & 2 & 715 & East Kilcoy Ck, Conondale NP, SEQ & & $M f l \times I$ \\
\hline $26^{\circ} 43^{\prime} \mathrm{S} 152^{\circ} 35^{\prime} \mathrm{E}$ & 2 & 680 & North Booloumba Ck, Conondale NP, SEQ & & $M f l \times 16$ \\
\hline $26^{\circ} 52^{\prime} \mathrm{S} \mid 5^{\circ} 1^{\circ} 35^{\prime} \mathrm{E}$ & 2 & 970 & Barker Ck, Bunya Mountains NP, SEQ & & $\mathrm{Mfa} \times 12$ \\
\hline $26^{\circ} 52^{\prime} \mathrm{S} 151^{\circ} 36^{\prime} \mathrm{E}$ & 2 & 930 & $\begin{array}{l}\text { Upper Tim Shea Ck, Bunya Mountains NP, } \\
\text { SEQ }\end{array}$ & & Mfa $\times 2$ \\
\hline $26^{\circ} 52^{\prime} \mathrm{S} 151^{\circ} 37^{\prime} \mathrm{E}$ & 3 & 685 & $\begin{array}{l}\text { Lower Tim Shea Ck, Bunya Mountains NP, } \\
\text { SEQ }\end{array}$ & & $M f a \times 1$ \\
\hline $26^{\circ} 53^{\prime} \mathrm{S} 151^{\circ} 36^{\prime} \mathrm{E}$ & 2 & 955 & Saddletree Ck, Bunya Mountains NP, SEQ & & $M f a \times 4$ \\
\hline $27^{\circ} 09^{\prime} \mathrm{S} 152^{\circ} 43^{\prime} \mathrm{E}$ & 3 & 205 & Jacky Ck, D'Aguilar NP, SEQ & & Mfa $\times 3$ \\
\hline $27^{\circ} 24^{\prime} \mathrm{S} 152^{\circ} 48^{\prime} \mathrm{E}$ & & 520 & Bullocky's Knob pond, D'Aguilar NP, SEQ & & $M f a \times 7$ \\
\hline $27^{\circ} 55^{\prime} \mathrm{S} 153^{\circ} 10^{\prime} \mathrm{E}$ & 2 & 425 & Sandy Ck, Tamborine NP, SEQ & & Mfa $\times 2$ \\
\hline $27^{\circ} 59^{\prime} \mathrm{S} 152^{\circ} 2$ I'E $^{\prime}$ & 3 & 730 & $\begin{array}{l}\text { Dalrymple Ck south branch, Main Range } \\
\text { NP, SEQ }\end{array}$ & & Mfa $\times 12 ; M f l \times 83$ \\
\hline $27^{\circ} 58^{\prime} \mathrm{S} 152^{\circ} 20^{\prime} \mathrm{E}$ & 4 & 665 & Dalrymple Ck, near Main Range NP, SEQ & & $\mathrm{Mfa} \times 3$ \\
\hline $28^{\circ} 03^{\prime} \mathrm{S} 152^{\circ} 22^{\prime} \mathrm{E}$ & 3 & 680 & Gap Ck West, Main Range NP, SEQ & $\mathrm{Mfl} \times 6$ & $M f a \times 2 ; M f l \times 413$ \\
\hline $28^{\circ} 15^{\prime} \mathrm{S} 152^{\circ} 28^{\prime} \mathrm{E}$ & 3 & 750 & Condamine R., near Main Range NP, SEQ & & $\mathrm{Mfl} \times 5$ \\
\hline $28^{\circ} 17^{\prime} \mathrm{S} 152^{\circ} 23^{\prime} \mathrm{E}$ & 3 & 895 & $\begin{array}{l}\text { Unnamed trib. Condamine R., Main Range } \\
\text { NP, SEQ }\end{array}$ & & $M f l \times 2$ \\
\hline $28^{\circ}$ II'S $153^{\circ} 07^{\prime} \mathrm{E}$ & 3 & 635 & Cainbable Ck, Lamington NP, SEQ & $\mathrm{Mfl} \times \mathrm{I}$ & $M f a \times 5 ; M f l \times 5$ \\
\hline $28^{\circ}$ II'S $153^{\circ} 08^{\prime} \mathrm{E}$ & I & 690 & $\begin{array}{l}\text { Unnamed trib. West Canungra Ck, } \\
\text { Lamington NP, SEQ }\end{array}$ & & Mfa $\times 2$ \\
\hline $28^{\circ} 12^{\prime} \mathrm{S} 153^{\circ} 06^{\prime} \mathrm{E}$ & & 690 & $\begin{array}{l}\text { Dam, upper Duck Ck, near Lamington NP, } \\
\text { SEQ }\end{array}$ & & $M f a \times 11$ \\
\hline $28^{\circ} 13^{\prime} \mathrm{S} 153^{\circ} 07^{\prime} \mathrm{E}$ & 3 & 775 & Stockyard Ck, Lamington NP, SEQ & & $M f a \times 1 ; M f l \times 7$ \\
\hline $28^{\circ} 13^{\prime} \mathrm{S} 153^{\circ} 08^{\prime} \mathrm{E}$ & 2 & 525 & Bundoomba Ck, Lamington NP, SEQ & & $M f l \times 4 I$ \\
\hline $28^{\circ} 13^{\prime} \mathrm{S} 153^{\circ} 08^{\prime} \mathrm{E}$ & 2 & 585 & Darraboola Ck, Lamington NP, SEQ & & $M f l \times 3$ \\
\hline $28^{\circ} 14^{\prime} \mathrm{S} 153^{\circ} 08^{\prime} \mathrm{E}$ & 3 & 780 & Morans Ck, Lamington NP, SEQ & & $M f l \times I$ \\
\hline $28^{\circ} 14^{\prime} \mathrm{S} 153^{\circ} 19^{\prime} \mathrm{E}$ & 2 & 230 & $\begin{array}{l}\text { Tallebudgera Ck, near Springbrook NP, } \\
\text { SEQ }\end{array}$ & & $M f l \times I$ \\
\hline $28^{\circ} 15^{\prime} \mathrm{S} 153^{\circ} 17^{\prime} \mathrm{E}$ & 2 & 200 & Couchy Ck, Numinbah, NENSW & & $M f l \times 6$ \\
\hline $28^{\circ} 19^{\prime} \mathrm{S} 152^{\circ} 52^{\prime} \mathrm{E}$ & 2 & 670 & Long Ck, Border Ranges NP, NENSW & & $M f l \times 3$ \\
\hline $28^{\circ} 22^{\prime} \mathrm{S} 153^{\circ} 04^{\prime} \mathrm{E}$ & 2 & 760 & $\begin{array}{l}\text { Unnamed trib. Brindle Ck, Border Ranges } \\
\text { NP, NENSW }\end{array}$ & & $M f l \times 2$ \\
\hline $28^{\circ} 22^{\prime} \mathrm{S} 153^{\circ} 04^{\prime} \mathrm{E}$ & 3 & 760 & Brindle Ck, Border Ranges NP, NENSW & $\mathrm{Mfl} \times 2$ & $\mathrm{Mfl} \times 5$ \\
\hline $28^{\circ} 33^{\prime} \mathrm{S} 153^{\circ} 15^{\prime} \mathrm{E}$ & 2 & 230 & Beech Ck, Nightcap NP, NENSW & & $\mathrm{Mfl} \times 2$ \\
\hline $28^{\circ} 33^{\prime} \mathrm{S} 153^{\circ} 17^{\prime} \mathrm{E}$ & 2 & 460 & Tuntable Ck, Nightcap NP, NENSW & Mfa $\times 1$ & Mfa $\times 1 ;$ Mfl $\times 29$ \\
\hline $28^{\circ} 36^{\prime} \mathrm{S} 153^{\circ} \mid 8^{\prime} \mathrm{E}$ & 2 & 210 & $\begin{array}{l}\text { Unnamed trib. Bat Cave Ck, Nightcap NP, } \\
\text { NENSW }\end{array}$ & Mfa $\times 4$ & Mfa $\times 4$ \\
\hline
\end{tabular}




\begin{tabular}{|c|c|c|c|c|c|}
\hline $\begin{array}{l}\text { Latitude \& } \\
\text { Longitude }\end{array}$ & $\begin{array}{l}\text { Stream } \\
\text { order }\end{array}$ & Alt & Locality & Oviposition & Egg masses \\
\hline $28^{\circ} 38^{\prime} \mathrm{S} 152^{\circ} 29^{\prime} \mathrm{E}$ & 2 & 500 & Yabbra Ck, Yabbra NP, NENSW & $\mathrm{Mfl} \times 2$ & $M f a \times 4 ; M f l \times 2$ \\
\hline $29^{\circ} 16^{\prime} \mathrm{S} 152^{\circ} 26^{\prime} \mathrm{E}$ & 3 & 200 & Desert Ck, Washpool NP, NENSW & Mit $\times 1$ & Mit $\times 6$ \\
\hline $29^{\circ} 26^{\prime} \mathrm{S} 152^{\circ} 10^{\prime} \mathrm{E}$ & 3 & 800 & Rockadooie Ck, Washpool NP, NENSW & & Mba $\times 1$ \\
\hline $30^{\circ} 15^{\prime} \mathrm{S} 153^{\circ} 05^{\prime} \mathrm{E}$ & I & 130 & Bucca Bucca Ck, Orara East SF, NENSW & Mit $\times 1$ & Mit $\times 10$ \\
\hline $32^{\circ} 03^{\prime} \mathrm{S} \mid 51^{\circ} 40^{\prime} \mathrm{E}$ & 2 & 370 & Sharpes Ck, Barrington Tops NP, NENSW & Mba $\times 1$ & Mba $\times 6$ \\
\hline $32^{\circ} 14^{\prime} \mathrm{S} \mid 51^{\circ} 46^{\prime} \mathrm{E}$ & 2 & 280 & Frying Pan Ck, Chichester SF, NENSW & & Mba $\times 1$ \\
\hline $33^{\circ} 12^{\prime} \mathrm{S} \mid 51^{\circ} 20^{\prime} \mathrm{E}$ & 2 & 60 & Little jilliby jilliby Ck, near Gosford, MENSW & Mit $\times 1$ & Mit x I \\
\hline $33^{\circ} 0 l^{\prime} \mathrm{S} \mid 51^{\circ} 26^{\prime} \mathrm{E}$ & I & 200 & Gap Ck, Watagans NP, MENSW & $\operatorname{Mba} \times 2$ & $\mathrm{Mba} \times 2$ \\
\hline TOTAL & & & & $\begin{array}{l}\text { Mba } \times 3 ; \text { Mfa } \times 5 \text {; } \\
\text { Mfl } \times 1 \text { I; Mit } \times 3\end{array}$ & $\begin{array}{l}\text { Mba } \times 10 ; \text { Mfa } \times 79 \\
\text { Mfl } \times 627 ; \text { Mit } \times 17\end{array}$ \\
\hline
\end{tabular}

observed. While in amplexus, the female gathered the eggs with her back feet, whereupon she rolled to one side and with a quick flick of the foot, kicked the eggs onto a nearby wet vertical rock surface. It was assumed that the eggs were fertilised by the male while being held in the female's foot just prior to being kicked on to the rock.

Hoskin and Hero (2008) describe the egg laying behaviour of M. coggeri as "pair in amplexus flicks eggs out of water to stick on rock or earth bank overhanging water" presumably based on a detailed account published subsequently by Hoskin (2010). Hoskin's is the only published account of oviposition for M. coggeri. Eggs were deposited on the roof and walls of the overhanging rock and adjacent earth bank of a stream, by the pair sitting or floating in shallow water and the female flicking eggs and water upwards using her hind legs. Hoskin likened the egg flicking behaviour to that shown in a photograph of M. fasciolatus in Anstis (2002, p. 218). Most eggs (approximately 300) were stuck to the roof of the overhang in an area $60 \times 30 \mathrm{~cm}$ about $20 \mathrm{~cm}$ above the water. Other eggs (approximately 150) were scattered on the adjacent sloping earth bank and rocks 10 to $30 \mathrm{~cm}$ from the water, with a small number of eggs in the pool.

Further information on the egg masses of the northeastern Australian species (M. carbinensis, M. coggeri, and M. schevilli) is presented in Anstis (2013), based largely on the unpublished observations and photographs of Tim Hawkes. Each of these species deposits eggs on moist near-vertical or sloping bank or rock above a stream pool, with oviposition behaviour assumed similar to that observed in M. fasciolatus (Knowles et al. 1998 unpubl.) and M. coggeri (Hoskin 2010). A count of the number of eggs within a single egg mass of M. schevilli was 74 and of four M. carbinensis egg masses averaged 196 (range 144-311).

In summary, existing published information on oviposition and egg mass morphology in Mixophyes is limited and at times contradictory. Oviposition is described from observations of a pair of M. balbus (Lewis 2000) and M. coggeri (Hoskin 2010) in the wild, and from a pair of M. fasciolatus in captivity (Banks et al. 2003). In the following sections of this paper we publish details of the observations of Knowles et al. (1998 unpubl.), with additional observations up to early 2012. We have observed oviposition in wild M. balbus (three times),
M. fasciolatus (five times), M. fleayi (11 times) and M. iteratus (three times) and have observed numerous egg masses of these species (summarised with locality details in Table 2). These observations greatly increase knowledge of the breeding biology of Mixophyes species, and clarify some previously published observations and assumptions on oviposition and egg masses in the genus.

\section{Methods}

The observations presented here were made during survey and monitoring activities targeting Mixophyes species in southeast Queensland and northeast New South Wales (e.g. Newell, Goldingay and Brooks 2013). These activities were typically at night, along stream transects, using spotlights or head torches to locate active animals. Where time and conditions permitted we observed pairs of Mixophyes in amplexus for extended periods, to document oviposition. In these cases we noted one or more of the following: time and location, prevailing weather conditions, method of oviposition and length of the oviposition sequence. We photographed the mode and site of oviposition, and the resulting egg masses.

In addition we observed many more Mixophyes egg masses during surveys and monitoring or through targeted searches. At times these targeted surveys covered hundreds of metres of stream, focusing on areas with breeding choruses and, for some species, large sample sizes were gathered from across their distributional range. Notes were made of the deposition site and the shape and dimensions of egg masses. For a subset of these we counted or estimated the number of eggs, described the development stage as per Gosner (1960) and measured a small series of eggs (capsule diameter)

\section{Results}

\section{Ovipositional process}

We observed two distinct ovipositional processes. Mixophyes fasciolatus and M. iteratus were observed (five and three times respectively) to deposit eggs terrestrially above water by kicking them onto an overhanging bank or log (referred to as Ovipositional Process 1) whilst M. balbus and M. fleayi deposited eggs aquatically in a constructed depression or 'nest' in the stream bed (referred to as Ovipositional 


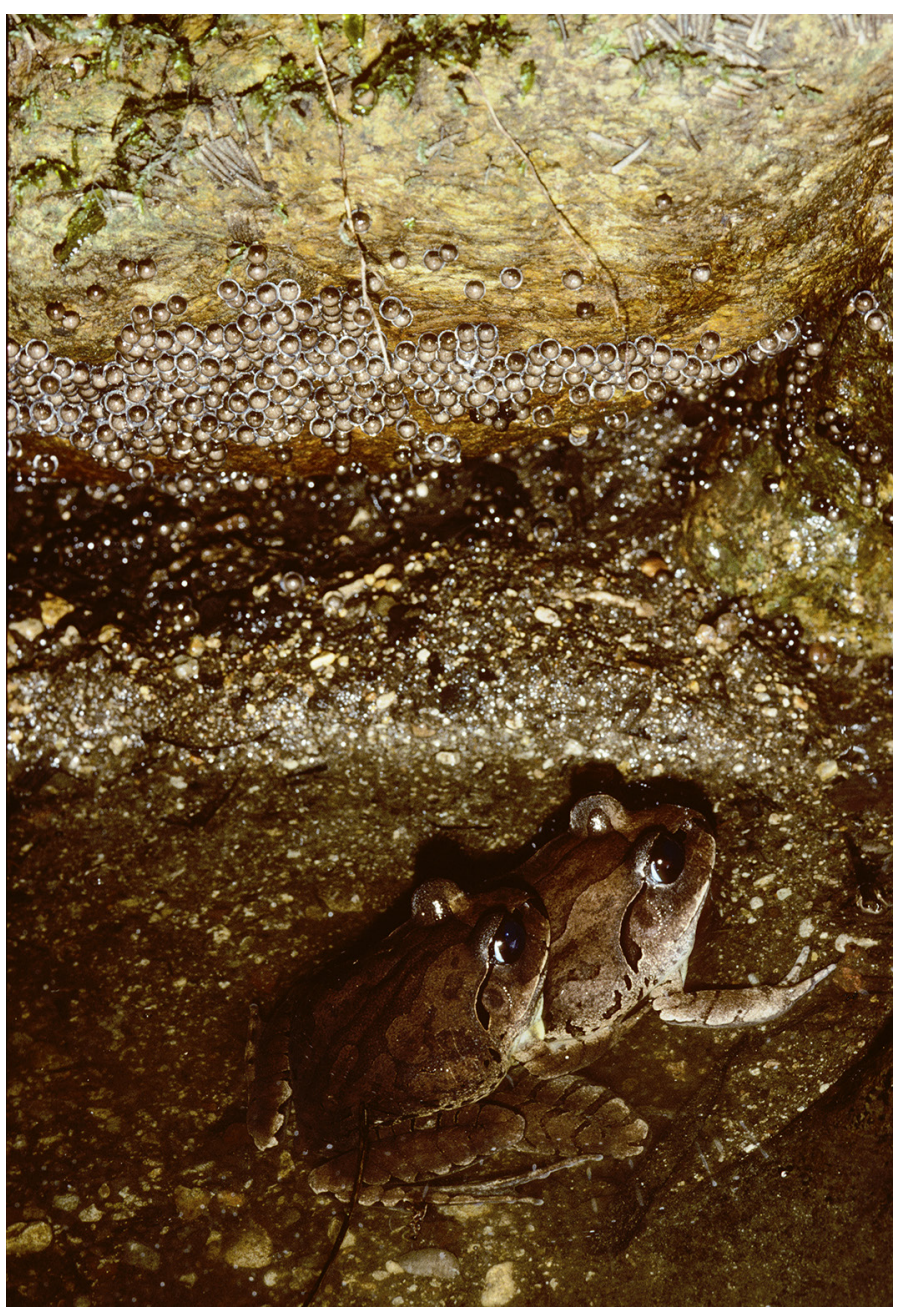

Figure I. A pair of Mixophyes fasciolatus in amplexus, during the process of spawning. Note that the pair is in the water, with the female using her forelimbs to brace against the stream bank. A number of eggs, already laid, are visible on the rock above the frogs. Unnamed tributary of Bat Cave Ck, Nightcap NP, NENSW, 24 Sep 1995. Photo, R. Knowles.

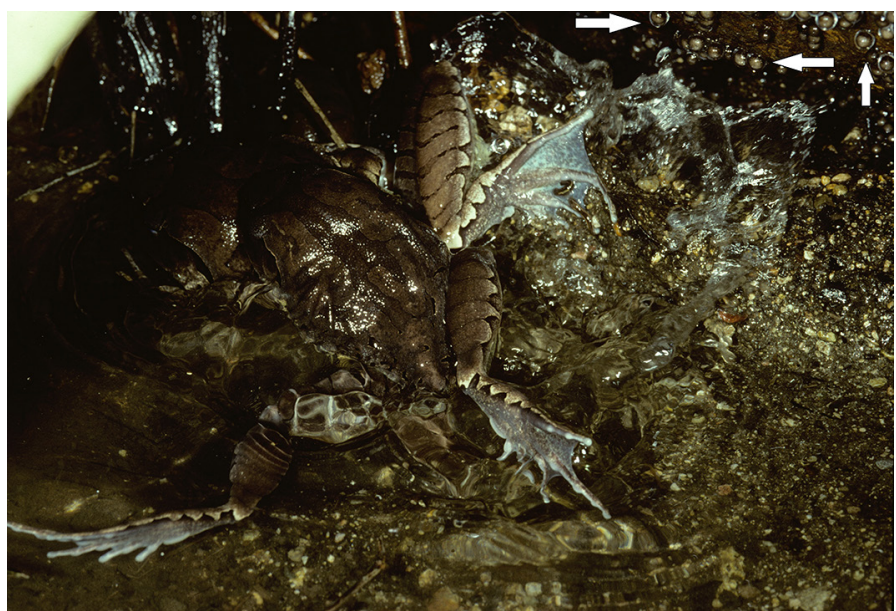

Figure 2. A photograph capturing the moment when a female Mixophyes fasciolatus, in amplexus, propels fertilised eggs out of the water and on to the embankment and overhanging rock. Arrows indicate eggs stuck on rock above water. Unnamed tributary of Bat Cave Ck, Nightcap NP, NENSW, 24 Sep 1995. Photo, R. Knowles.
Process 2). Ovipositional Process 2 was observed three times for M. balbus and 11 times for M. fleayi.

\section{Ovipositional Process 1: observed in M. fasciolatus and M. iteratus}

The following is a description of the ovipositional process of M. fasciolatus, at an unnamed tributary of Bat Cave Creek, Nightcap NP, NENSW (Table 2), 24 Sep1995 (five amplectant pairs observed between 00:00 and 02:20hrs).

1. Males were calling from terrestrial positions, typically within $5 \mathrm{~m}$ of the stream, and facing the stream. Females were attracted to the calling males.

2. Amplexus occurred terrestrially. The female, with the male on her back, moved to the stream where she moved into the water and along the bank. Amplexus was initially axillary, but shifted at times during oviposition to be pectoral or inguinal.

3. The amplexing pair floated in the water facing the chosen egg deposition site (a more or less vertical surface of an overhanging rock, which formed part of the bank), see Figure 1. The female spread her forearms out in front of her body under the water: this appeared to brace the pair.

4. Just prior to laying a batch of eggs, the female moved the pair sidewards, either to the right or to the left, less than one centimetre.

5. The male then moved his vent down into contact with the female and squeezed his hind legs inwards.

6. As the male moved his vent down eggs were expelled from the female's cloaca. They were presumably fertilised by the male during his downward movement observed in 5 .

7. The female moved either her right or left hind limb rapidly through the water with an upward flicking motion towards the oviposition site, creating a clearly audible splash of water. Eggs were propelled with the water. The movement of the eggs from the female's cloaca to the position where they were propelled out of the water by the webbing of the foot was not observed. The movement of the female's leg in propelling the eggs was rapid and it was difficult to determine exactly what was occurring with the naked eye. Photographs show however, that a splayed webbed foot is likely to be responsible for propelling the eggs from the water onto the deposition site (Figure 2).

8. The eggs were propelled approximately $10-15 \mathrm{~cm}$ towards the deposition site (the overhanging rock) where the eggs adhered (Figures 1, 2 and 3).

9. The female's motion, in propelling eggs towards the deposition site, was so vigorous that her body swung around to a position almost parallel to the bank, before she returned to a position facing the bank. As a result of this movement, the male's body was partially displaced from the female (Figure 2), before he returned to the normal amplexing position (Figure 1).

For one pair, oviposition took place between about 00:00 and 00:41hrs with egg laying bouts (steps 4-9 above) at intervals of 15-55 seconds with a mean of 31 seconds ( $\mathrm{n}=$ 
9). In M. iteratus the interval between bouts of egg laying ranged between 34 seconds and 3 minutes 36 seconds, with a mean interval of 1 minute and 24 seconds $(n=11)$.

\section{Ovipositional Process 2: observed in M. balbus and M. fleayi}

The following is a description of the ovipositional process of two pairs of M. fleayi, Yabbra Creek, NENSW (Table 2), 07 Feb 2000.

1. Males were calling from terrestrial positions, within the stream bed or within $5 \mathrm{~m}$ of the stream, and facing the stream. Females were attracted to the calling male.

2. Amplexus occurred terrestrially and was axillary. The female, with the male on her back, moved down to the stream.

3. The pair moved along the creek to a riffle where the stream bed comprised small stones under approximately $2 \mathrm{~cm}$ of gently flowing water. The pair made several rotations in the one spot, with the female shuffling her feet. This resulted in a more or less circular depression or 'nest' amongst the stones. No eggs were laid during this nest construction phase.

4. Just prior to laying a batch of eggs, the amplexing pair made a small downward movement into the nest area. The female rapidly ventriflexed so that her dorsum arched downwards, with her head held up. Simultaneously the male quickly placed his feet on the female's groin or upper legs (Figures 4 and 5), before both frogs dropped back down together again. During this process the female extruded a small clump of eggs (possibly 20-30 eggs) (Figure 4) presumably fertilised by the male as extruded.

5. The pair rotated, usually $45-90^{\circ}$, in an anti-clockwise direction, with the female shuffling her feet backwards into the walls of the nest, presumably pushing the eggs into the substrate.

6. The pair then pushed downwards into the nest area again, with their bodies lower than a normal sitting position (Figure 5). After a pause of up to several minutes the pair repeated steps 4 and 5, always rotating in an anticlockwise direction after laying a batch of eggs.

For one pair, 14 bouts of egg laying (steps 4-6 above) occurred at intervals of between 2 and 6 minutes (mean $=$ 3.8 minutes), and the mean interval for 17 bouts in a second pair was 4.2 minutes. In M. balbus (Sharpes Ck, Barrington Tops NP, NENSW, on 11 Feb 2000 between 22:10 and 23:28 hours), 25 bouts of egg laying took place at intervals between 1.5 and 5 minutes (mean $=3.08$ minutes).

\section{Oviposition sites and egg masses}

The different ovipositional processes and depositional sites produced distinctive forms of egg masses. These observations enabled targeted searches of potential breeding sites, in particular in areas in proximity to choruses of calling males. Furthermore, as eggs take many days to hatch, egg masses were present well after breeding events. Egg masses are also locatable during daylight hours which enabled increased and more efficient search effort.

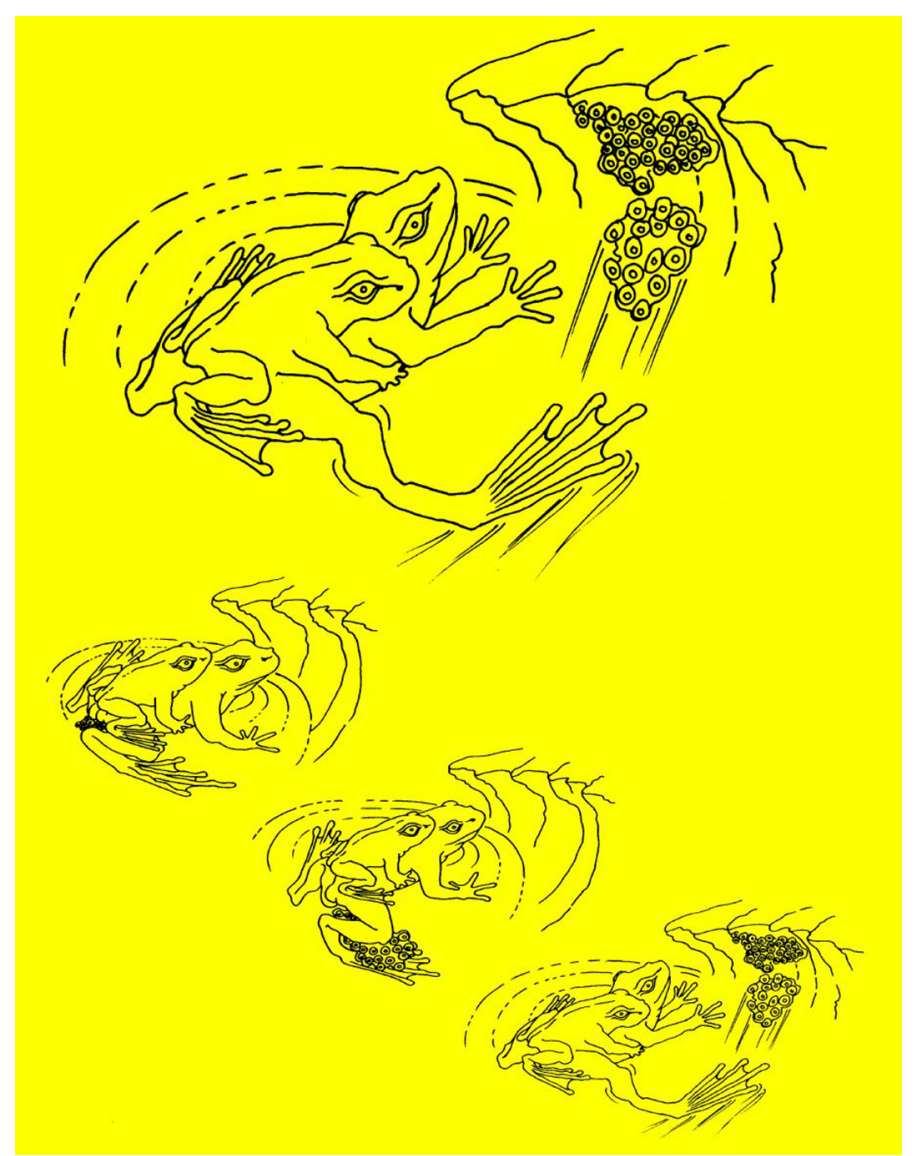

Figure 3. A stylised illustration of Ovipositional Process I (e.g. Mixophyes fasciolatus). The amplectant pair of frogs is floating in water, braced against a partially undercut/ overhanging stream bank. Artwork, G. Hancox.

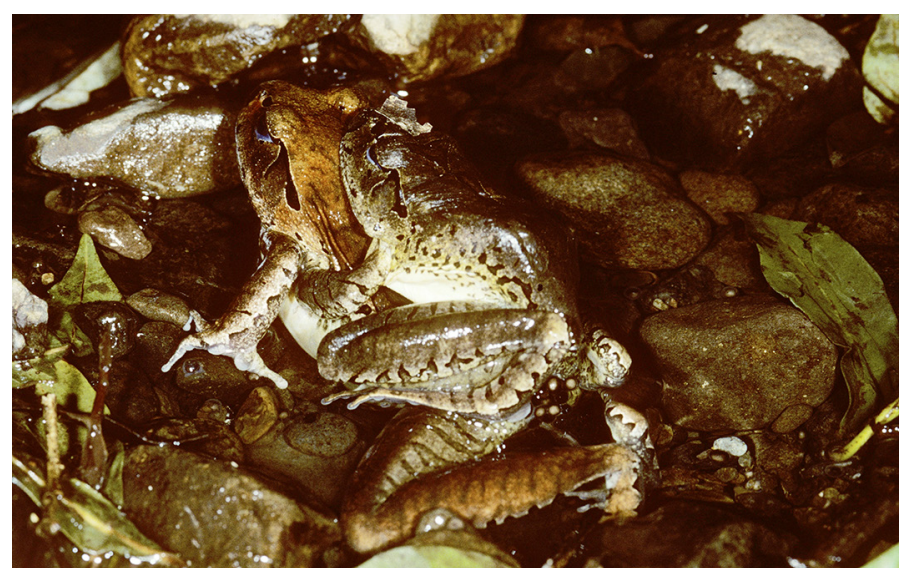

Figure 4. A pair of Mixophyes fleayi in amplexus, during the process of spawning. Gap Creek West, Main Range National Park, SEQ, I5 Sep 1996. Note that the pair has created a shallow depression in the stream bed amongst the gravel substrate, in shallow running water. A small clump of eggs can be seen leaving the female's cloaca (oviposition step 4). Photo, R. Knowles.

As a result, the number of egg masses detected (over 700) was substantially higher than the number of occasions on which we observed oviposition (22 occasions, see Table 2). The morphology of egg masses resulting from the two ovipositional processes are described below with quantitative data summarised in Tables 3 and 4. 
Table 3. Dimensions of Mixophyes egg masses from Ovipositional Process I. Refer to Table 2 for additional locality details. Atypical egg masses (i.e. those with very low numbers of eggs or with eggs in scattered or diffuse clumps or obviously contained multiple clutches of eggs) are excluded. SE = standard error of the mean. Species abbreviations as per Table 2. All measurements are in millimetres.

\begin{tabular}{|c|c|c|c|c|c|c|c|c|c|c|c|c|c|c|c|c|c|}
\hline \multirow[b]{2}{*}{ Species } & \multirow[b]{2}{*}{ Location } & \multicolumn{4}{|c|}{ Shortest dimension } & \multicolumn{4}{|c|}{ Longest dimension } & \multicolumn{4}{|c|}{ Lowest egg above water } & \multicolumn{4}{|c|}{ Highest egg above water } \\
\hline & & Mean & SE & Range & $\mathrm{n}$ & Mean & SE & Range & $n$ & Mean & SE & Range & $\mathrm{n}$ & Mean & SE & Range & $\mathrm{n}$ \\
\hline Mfa & $\begin{array}{l}\text { Kroombit Ck } \\
\text { north branch, } \\
\text { Kroombit Tops } \\
\text { NP, SEQ }\end{array}$ & & & & & 600 & & & । & & & & & & & & \\
\hline Mfa & $\begin{array}{l}\text { Barker } \\
\text { Ck, Bunya } \\
\text { Mountains NP, } \\
\text { SEQ }\end{array}$ & & & & & 478 & 54.4 & $\begin{array}{l}160 \\
-850\end{array}$ & 4 & 50 & 0.0 & $\begin{array}{l}50 \\
-50\end{array}$ & 2 & 143 & 27.5 & $\begin{array}{l}115 \\
-170\end{array}$ & 2 \\
\hline Mfa & $\begin{array}{l}\text { Bullocky's Knob } \\
\text { pond, D'Aguilar } \\
\text { NP, SEQ }\end{array}$ & 65 & & & । & 183 & 44.4 & $\begin{array}{l}100 \\
-300\end{array}$ & 4 & 90 & & & । & 178 & 13.0 & $\begin{array}{l}155 \\
-200\end{array}$ & 3 \\
\hline Mfa & $\begin{array}{l}\text { Sandy Ck, } \\
\text { Tamborine NP, } \\
\text { SEQ }\end{array}$ & & & & & 275 & 25.0 & $\begin{array}{l}250 \\
-300\end{array}$ & 2 & & & & & 150 & & & । \\
\hline Mfa & $\begin{array}{l}\text { Dalrymple Ck } \\
\text { south branch, } \\
\text { Main Range NP, } \\
\text { SEQ }\end{array}$ & 158 & 33.8 & $\begin{array}{l}100 \\
-230\end{array}$ & 4 & 223 & 38.3 & $\begin{array}{l}120 \\
-500\end{array}$ & 9 & 32 & 14.7 & $\begin{array}{l}0 \\
-100\end{array}$ & 7 & 157 & 13.8 & $\begin{array}{l}115 \\
-220\end{array}$ & 9 \\
\hline Mfa & $\begin{array}{l}\text { Gap CkWest, } \\
\text { Main Range NP, } \\
\text { SEQ }\end{array}$ & 64 & & & । & 163 & & & । & 27 & & & । & 96 & & & । \\
\hline Mfa & $\begin{array}{l}\text { Dam, upper } \\
\text { Duck Ck, near } \\
\text { Lamington NP, } \\
\text { SEQ }\end{array}$ & & & & & 183 & 49.1 & $\begin{array}{l}100 \\
-270\end{array}$ & 3 & & & & & 95 & 23.6 & $\begin{array}{l}60 \\
-160\end{array}$ & 4 \\
\hline Mfa & $\begin{array}{l}\text { Yabbra Ck, } \\
\text { Yabbra NP, } \\
\text { NENSW }\end{array}$ & 227 & 62.3 & $\begin{array}{l}150 \\
-350\end{array}$ & 3 & 320 & 20.8 & $\begin{array}{l}280 \\
-350\end{array}$ & 3 & 50 & 28.9 & $\begin{array}{l}0 \\
-100\end{array}$ & 3 & 223 & 29.6 & $\begin{array}{l}180 \\
-280\end{array}$ & 3 \\
\hline Mfa & $\begin{array}{l}\text { Unnamed trib. } \\
\text { Bat Cave Ck, } \\
\text { Nightcap NP, } \\
\text { NENSW }\end{array}$ & 125 & 26.3 & $\begin{array}{l}80 \\
-200\end{array}$ & 4 & 245 & 24.7 & $\begin{array}{l}180 \\
-300\end{array}$ & 4 & & & & & & & & \\
\hline Mfa & All sites ( $n=9$ ) & 149 & 22.7 & $\begin{array}{l}64 \\
-350 \\
\end{array}$ & 13 & 273 & 29.6 & $\begin{array}{l}100 \\
-850\end{array}$ & 31 & 42 & 9.8 & $\begin{array}{l}0 \\
-100\end{array}$ & 14 & 154 & 11.1 & $\begin{array}{l}60- \\
280\end{array}$ & 23 \\
\hline Mit & $\begin{array}{l}\text { Desert Ck, } \\
\text { Washpool NP, } \\
\text { NENSW }\end{array}$ & 157 & 56.7 & $\begin{array}{l}100 \\
-270\end{array}$ & 3 & 387 & 109.1 & $\begin{array}{l}240 \\
-600\end{array}$ & 3 & 67 & 27.3 & $\begin{array}{l}30 \\
-120\end{array}$ & 3 & 137 & 18.6 & $\begin{array}{l}100 \\
-160\end{array}$ & 3 \\
\hline Mit & $\begin{array}{l}\text { Bucca Bucca } \\
\text { Ck, Orara East } \\
\text { SF, NENSW }\end{array}$ & 198 & 20.9 & $\begin{array}{l}120 \\
-300\end{array}$ & 9 & 347 & 25.2 & $\begin{array}{l}250 \\
-500\end{array}$ & 9 & 45 & 5.0 & $\begin{array}{l}40 \\
-50\end{array}$ & 2 & 149 & 31.0 & $\begin{array}{l}108 \\
-210\end{array}$ & 3 \\
\hline Mit & All sites $(n=2)$ & 188 & 20.3 & $\begin{array}{l}100 \\
-300\end{array}$ & 12 & 357 & 30.3 & $\begin{array}{l}240 \\
-600\end{array}$ & 12 & 58 & 15.9 & $\begin{array}{l}30 \\
-120\end{array}$ & 5 & 143 & 16.4 & $\begin{array}{l}100 \\
-210\end{array}$ & 6 \\
\hline
\end{tabular}

\section{Eggs deposited out of water}

We observed 79 egg masses of M. fasciolatus from 19 sites in southeast Queensland and northeast NSW and 17 of M. iteratus from three sites in northeast and mid-east NSW (Table 2). Dimensions of egg masses of these species are provided in Table 3.

The egg masses of M. fasciolatus were large (Table 5) with a mean of 1461 eggs (range 740-2800, $n=8$ ) and generally rectangular-shaped, extending, on average, along $273 \mathrm{~mm}$ of stream bank, $\mathrm{n}=13$, and averaging $149 \mathrm{~mm}$ in vertical extent, $\mathrm{n}=31$ egg masses). The mean depth of water beneath the egg masses of M. fasciolatus was $231 \mathrm{~mm}(\mathrm{n}=$ 12 , range $40-450 \mathrm{~mm}$ ) and eggs were positioned between 0 and $280 \mathrm{~mm}$ above the water line (Table 3).

The eggs of $\mathrm{M}$. fasciolatus are propelled out of the water onto an adjacent bank or overhanging structure (Figures 6-10). When selecting oviposition sites within streams, M. fasciolatus preferred pools. Oviposition sites were on steeply sloping, partially or completely overhanging banks (Figures 6, 7, 9 and 10) or tree trunks, beneath 
Table 4. Dimensions of Mixophyes egg masses from Ovipositional Process 2. Refer to Table 2 for additional locality details. Atypical egg masses (i.e. those with very low numbers of eggs or with eggs in scattered or diffuse clumps) are excluded. $\mathrm{SE}=$ standard error of the mean. Species abbreviations as per Table 2.

\begin{tabular}{|c|c|c|c|c|c|c|c|c|}
\hline \multirow[b]{2}{*}{ Species } & \multirow[b]{2}{*}{ Locality } & \multicolumn{3}{|c|}{$\begin{array}{l}\text { Shortest dimension } \\
(\mathrm{mm})\end{array}$} & \multicolumn{4}{|c|}{$\begin{array}{l}\text { Longest dimension } \\
\qquad(\mathrm{mm})\end{array}$} \\
\hline & & Mean & SE & Range & Mean & SE & Range & $\mathrm{n}$ \\
\hline Mba & Rockadooie Ck, Washpool NP, NENSW & 70 & & & 80 & & & । \\
\hline Mba & Sharpes Ck, Barrington Tops NP, NENSW & 95 & 5.0 & $70-100$ & 110 & 7.3 & $90-140$ & 6 \\
\hline Mba & Frying Pan Ck, Chichester SF, NENSW & 120 & & & 120 & & & I \\
\hline Mba & Gap Ck, Watagans NP, MENSW & 65 & & & 70 & & & । \\
\hline Mba & All sites $(n=4)$ & 92 & 6.2 & $65-120$ & 103 & 7.3 & $70-140$ & 9 \\
\hline $\mathrm{Mfl}$ & East Kilcoy Ck, Conondale NP, SEQ & 100 & & & 100 & & & । \\
\hline $\mathrm{Mfl}$ & Dalrymple Ck south branch, Main Range NP, SEQ & 123 & 4.4 & $80-190$ & 149 & 6.9 & $80-260$ & 36 \\
\hline $\mathrm{Mfl}$ & Gap Ck West, Main Range NP, SEQ & 104 & 2.6 & $55-180$ & 125 & 4.4 & $55-250$ & 79 \\
\hline $\mathrm{Mfl}$ & Condamine R., near Main Range NP, SEQ & 120 & 10.0 & $110-130$ & 140 & 10.0 & $130-150$ & 2 \\
\hline $\mathrm{Mfl}$ & Cainbable Ck, Lamington NP, SEQ & 120 & & & 155 & & & । \\
\hline $\mathrm{Mfl}$ & Darraboola Ck, Lamington NP, SEQ & 103 & 2.5 & $100-105$ & 103 & 2.5 & $100-105$ & 2 \\
\hline $\mathrm{Mfl}$ & Bundoomba Ck, Lamington NP, SEQ & 116 & 9.1 & $80-150$ & 124 & 10.7 & $80-150$ & 8 \\
\hline $\mathrm{Mfl}$ & Long Ck, Border Ranges NP, NENSW & 58 & 2.5 & $55-60$ & 63 & 2.5 & $60-65$ & 2 \\
\hline $\mathrm{Mfl}$ & Yabbra Ck, Yabbra NP, NENSW & 100 & & & 160 & & & I \\
\hline $\mathrm{Mfl}$ & All sites $(n=9)$ & 109 & 2.2 & $55-190$ & 130 & 3.5 & $55-260$ & 132 \\
\hline
\end{tabular}

washed out stumps (Figure 8), or on fallen logs above water. Most egg masses were observed on steeply sloping (i.e. near vertical) surfaces, but on a few occasions (e.g. at least four egg masses at Dalrymple Ck south branch, Main Range NP, SEQ) they were also observed on the ceiling of undercut banks (i.e. deposited on a more or less horizontal surface above the water). Often a feature of oviposition sites on steeply sloping banks was the presence of overhanging vegetation (see Figures 7 and 9) which presumably provided protection of eggs from direct sunlight and or desiccation, particularly at sites in open forest (e.g. Dalrymple Ck south branch, Main Range NP, SEQ). Some oviposition sites contained clutches of eggs from numerous pairs (Figures 9 and 10) and some oviposition sites were used on multiple occasions. Several times we also observed egg masses with very low numbers of eggs or with eggs in scattered or diffuse clumps, possibly as a result of the pair choosing an unsuitable oviposition site and subsequently moving, harassment by other males, and / or disturbance by nocturnal predators such as rough-scaled snake Tropidechis carinatus which frequented oviposition sites. Often eggs were several layers deep. They were typically firmly attached to the substrate and each other, such that they were not easy to dislodge. On several occasions hatchling tadpoles were seen wriggling free of eggs and dropping or wriggling down to the water below.

Unlike other Mixophyes, M. fasciolatus often calls around and breeds in lentic (pond) as well as lotic (stream) habitats. Egg masses were observed at two ponds in southeast Queensland. The first site at Bullocky's Knob, D'Aguilar NP (Table 2) is a steep sided pond probably formed by quarrying rock. At this site M. fasciolatus egg masses were deposited in similar situations and
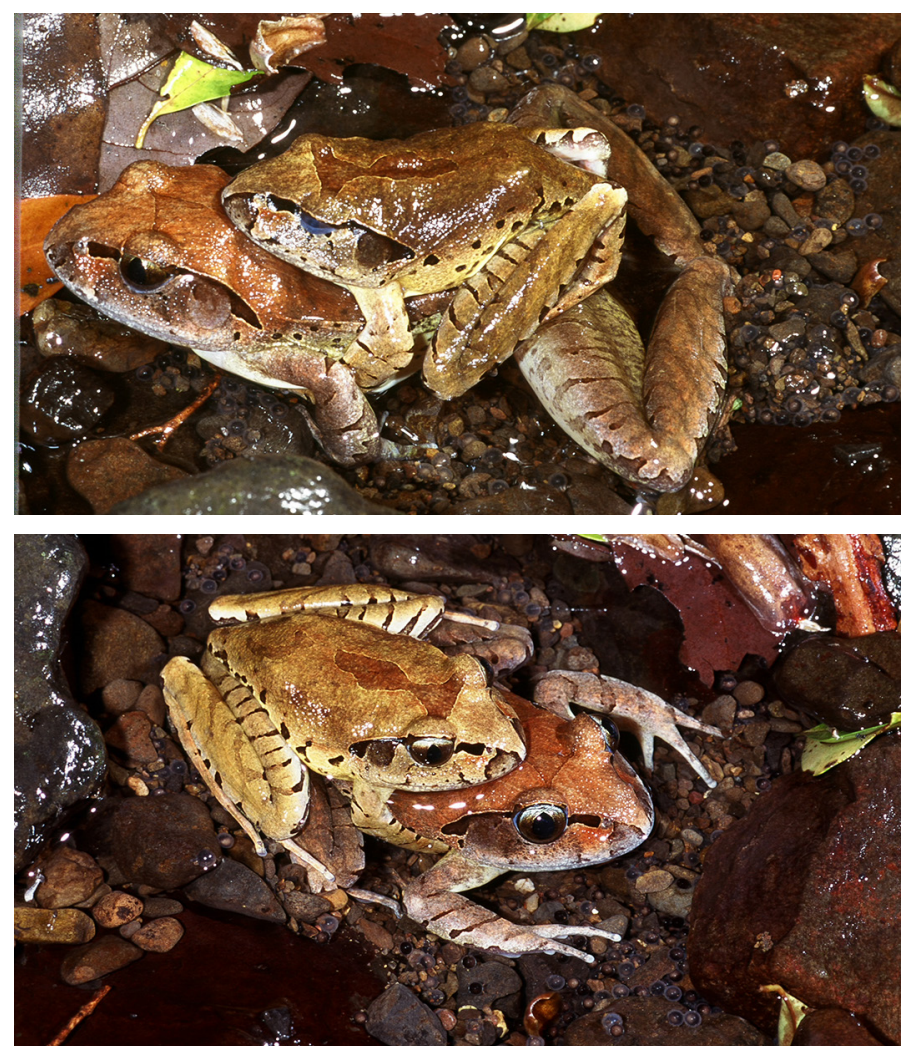

Figure 5. A pair of spawning Mixophyes fleayi, Gap Creek West, Main Range National Park, SEQ 05 Dec 200 I.The pair has created a shallow depression in the stream bed amongst the gravel substrate, in shallow running water (oviposition step 3). The upper image shows the pair during oviposition step 4 , at the instance when the female expelled a small clump of eggs (see Figure 4). The lower photo shows the pair resting within the nest hollow between bouts of egg laying (oviposition step 6). Photos, H.B. Hines. 

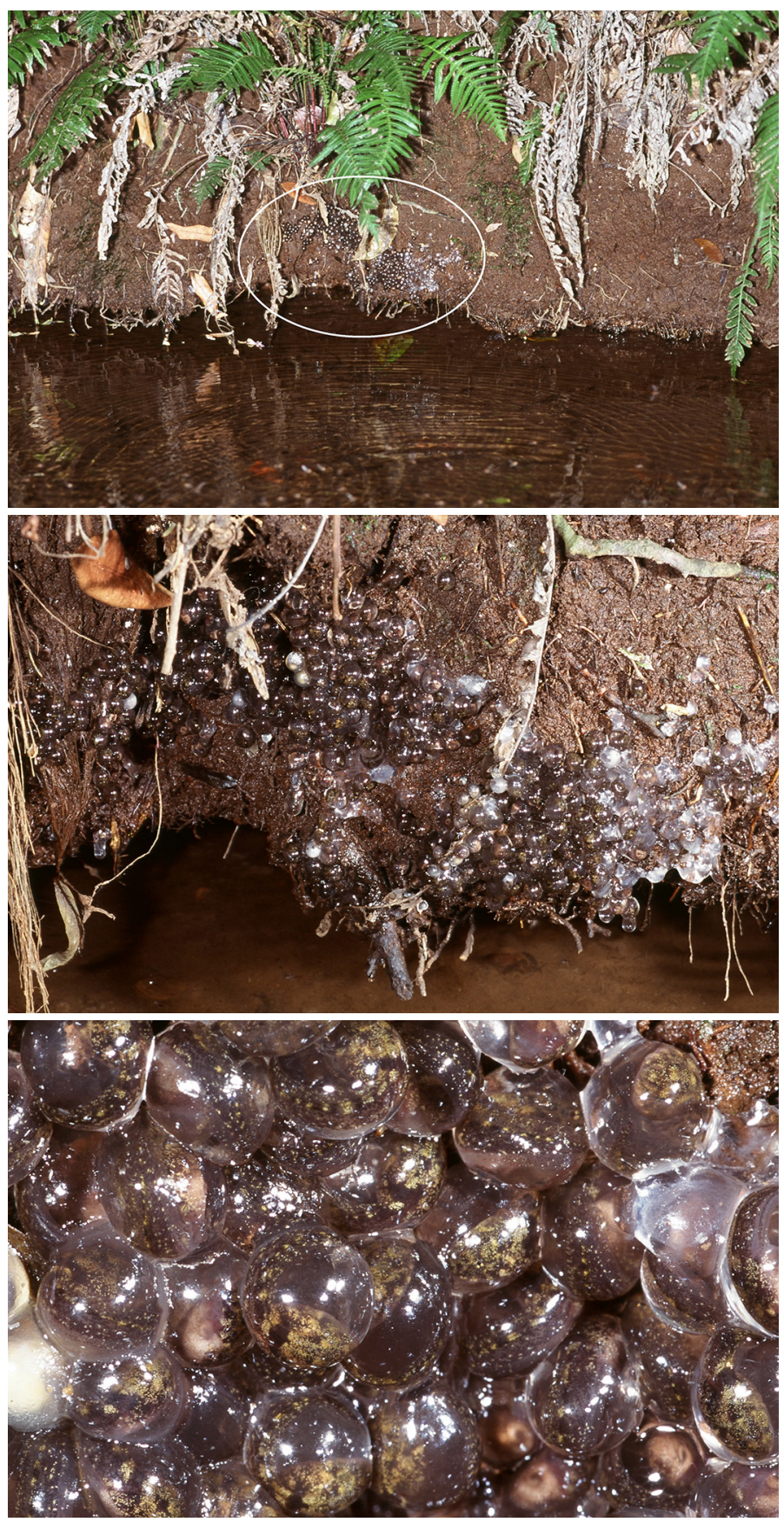

Figure 6. Oviposition site and egg mass of Mixophyes fasciolatus, Stockyard Ck, Lamington NP, SEQ, I I Dec 200 I. Top - oviposition site on bank of stream (circled in white). Centre - close-up of egg mass with some overhanging debris removed, the opaque gelatinous material on the right are the remnants of capsules following hatching of tadpoles and some unviable eggs. Bottom - close-up of eggs, showing welldeveloped strongly pigmented tadpoles (stage 23) just prior to hatching. Photos, H.B. Hines.

resembled those typical of stream habitats (seven egg masses, all deposited above water on a more or less vertical bank). The second pond was a small, shallow farm dam in upper Duck Ck, near Lamington NP (Table 2). Most of the perimeter of this dam was gently sloping, such that typical oviposition sites of M. fasciolatus were limited. Of the 11 egg masses observed here, six were on a more or less vertical low earthen bank and four were
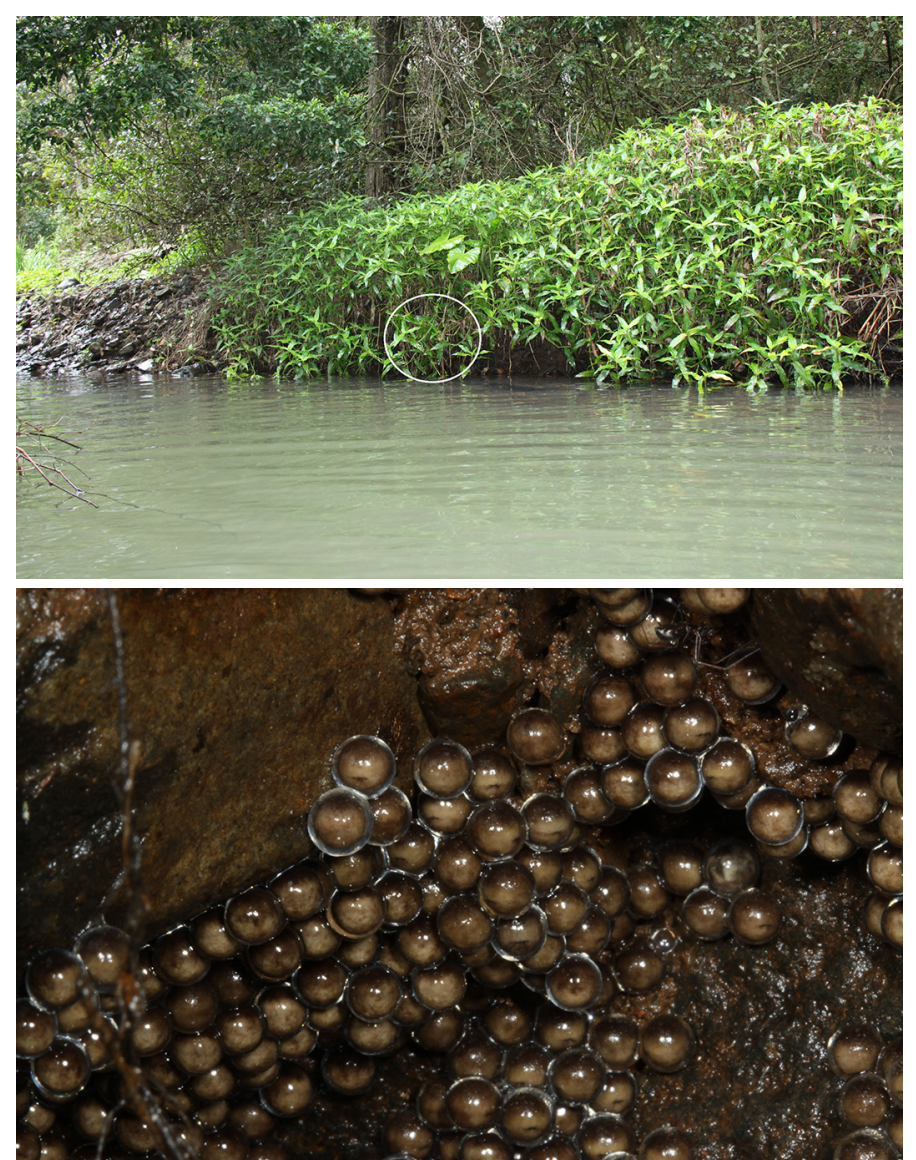

Figure 7. Oviposition site and egg mass of Mixophyes fasciolatus, Dalrymple Ck south branch, Main Range NP, SEQ, 17 Oct 2011. Top - oviposition site on the stream bank (circled in white), protected from sunlight by dense growth of Pollia crispata. Bottom - close-up of the eggs (stage 9-10), attached to rocks and earth of the more or less vertical stream bank Photos, H.B. Hines.

deposited out of water onto the sides of a fallen log that sloped from the bank into the water. Another large egg mass however, was deposited on very gently sloping mud about $60 \mathrm{~cm}$ from the water's edge.

Whilst the development of egg masses was not monitored, rotting eggs were noted in at least eight $M$. fasciolatus egg masses from six sites (e.g. Figure 10), of which most or all eggs were affected in four egg masses. A small proportion of desiccated eggs were also observed at several sites. At the dam in upper Duck Ck, near Lamington NP, SEQ (Table 2) one of the egg masses was almost entirely desiccated: this dam is in open forest and the egg masses were laid on a fallen log above water, with no overhanging vegetation providing protection from sunlight.

The egg masses of M. iteratus were large (Table 5) with a mean of 1988 eggs (range 1660-2200 eggs, $n=4$ ) and roughly rectangular-shaped with mean dimensions of 188 x $357 \mathrm{~mm}(\mathrm{n}=12$, Table 3$)$. Egg masses were positioned over water (Figure 11), 30-280 mm deep (mean depth $120 \mathrm{~mm}, \mathrm{n}=13)$, and the eggs were placed between 30 and $210 \mathrm{~mm}(\mathrm{n}=6)$ above the water line (Table 3$)$. All of the egg masses of $M$. iteratus were deposited on the ceiling of undercut banks of the stream pools (i.e. deposited on a more or less horizontal surface above the water). 

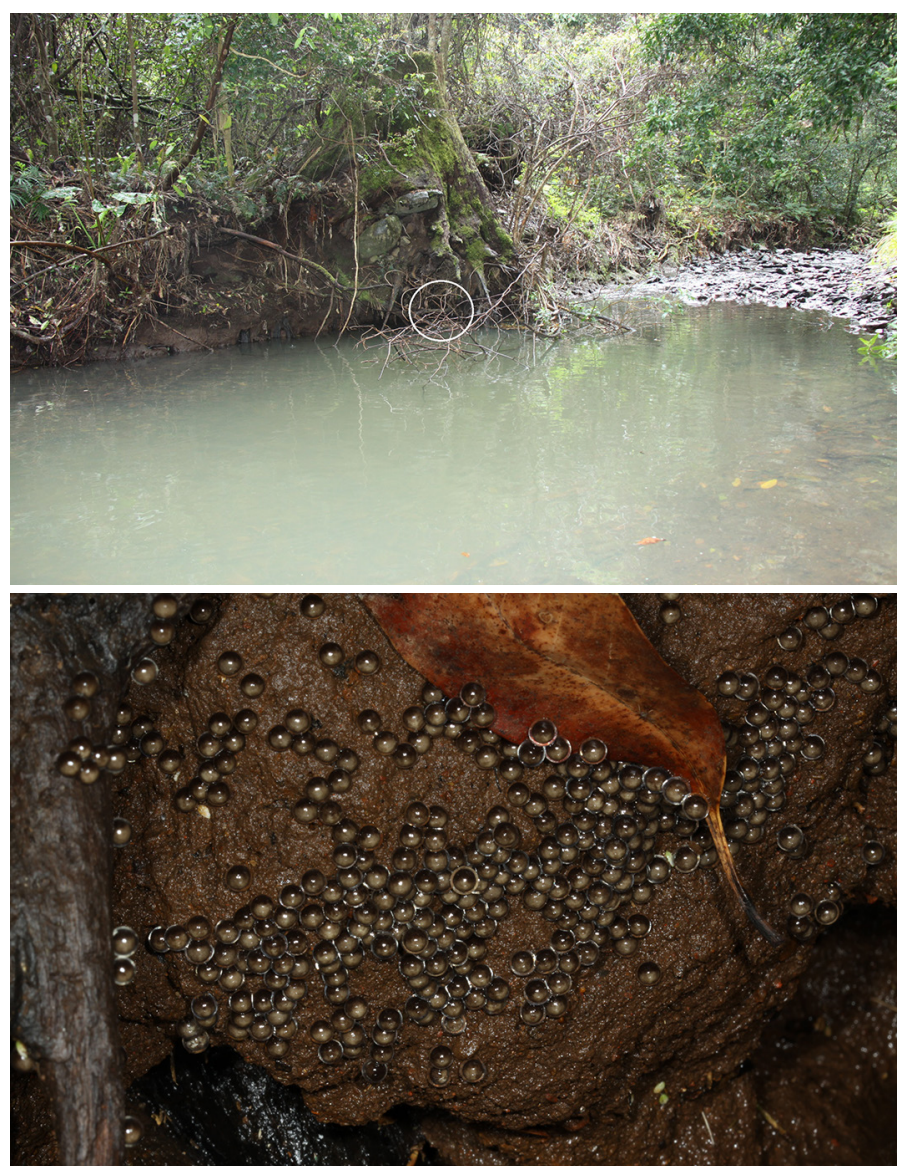

Figure 8. Oviposition site and egg mass of Mixophyes fasciolatus, Dalrymple Ck south branch, Main Range NP, SEQ,

I7 Oct 201 I. Top - oviposition site, underneath a partially washed out tree stump (circled in white). Bottom - close-up of eggs (stage 8-9) attached to rocks and earth on the sides and ceiling of the undercut bank. Photos, H.B. Hines.

A feature of pools of streams in eastern Australia is the occurrence of undercut banks. These are commonly associated with the roots of trees and shrubs that grow adjacent to the stream, which bind the soil and stones of the banks, resulting in a more or less stable undercut created by the long-term erosional effects of stream flow. Undercut banks vary in size, but in streams where Mixophyes occur they are typically $20-30 \mathrm{~cm}$ deep and with a ceiling 5-10 $\mathrm{cm}$ above the water, extending along a bank for many metres. Undercut banks do not occur along riffle zones. From our limited observations $M$. iteratus appears to rely on the ceilings of these undercut banks for oviposition. As it is difficult to survey beneath undercut banks it is possible that these sites are also used by other Mixophyes species with Ovipositional Process 1, as shown for M. coggeri by Hoskin (2010) and our observations of four egg masses of M. fasciolatus on the ceilings of undercut banks at Dalrymple Ck south branch, Main Range NP, SEQ.

\section{Eggs laid in shallow, gently flowing water}

We observed 10 egg masses of M. balbus from four sites in northeast and mid-east NSW and 627 egg masses of M. fleayi from 19 sites across the full extent of its geographical range, which extends from NENSW to SEQ (Table 2). These two species shared similar oviposition
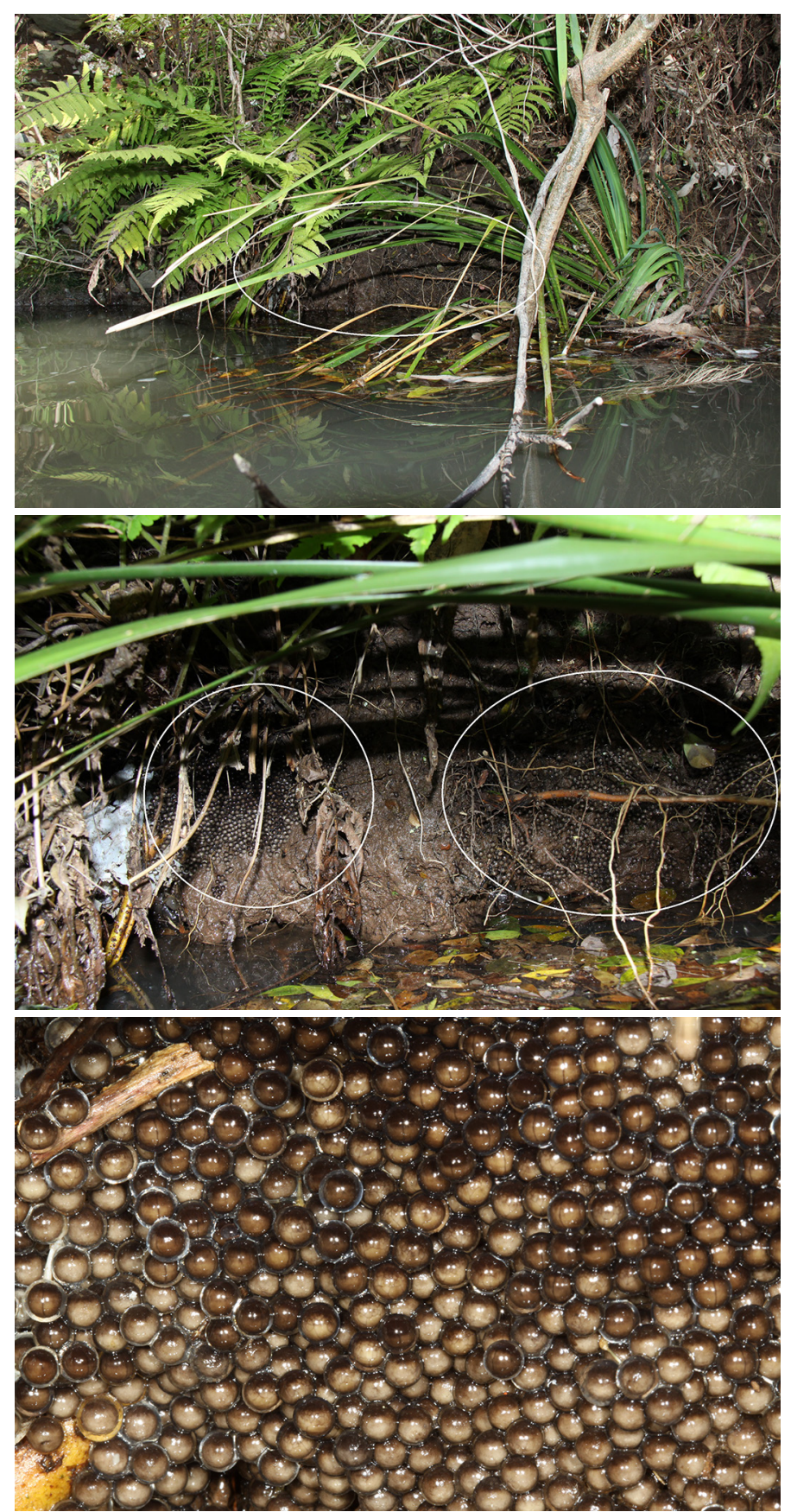

Figure 9. Oviposition site and egg masses of Mixophyes fasciolatus, Dalrymple Ck south branch, Main Range NP, SEQ, 17 Oct 2011. Top - oviposition site of two egg masses on a more or less vertical stream bank (circled in white), partially obscured by overhanging vegetation. Centre - closer view of the oviposition site and two egg masses. Bottom - close-up of the eggs (stage 4-8) of the left hand egg mass, showing the density of eggs in some situations. Photos, H.B. Hines.

sites with similar egg mass shape and dimensions (Table 4) (Figures 12-16). Typically, eggs were placed in gently flowing water of riffle zones within a rounded nest constructed in the substrate of sand, gravel and or leaf litter ( $100 \mathrm{~mm}$ diameter, $30-40 \mathrm{~mm}$ deep). The mean number of eggs per egg mass for M. fleayi was 576 eggs (range 120-1750, $\mathrm{n}=30$ ), while for $\mathrm{M}$. balbus there was a mean of 448 eggs per egg mass (range $130-824, n=8$; one-tailed t-test, $t=0.26$, n.s.). 
Table 5. The number of eggs observed in egg masses of Mixophyes species. Refer to Table 2 for additional locality details. Species abbreviations as per Table 2. Atypical egg masses (i.e. those with very low numbers of eggs or with eggs in scattered or diffuse clumps) are excluded.

\begin{tabular}{|c|c|c|c|c|}
\hline Species & Location & Date & Number of eggs & Count or estimate \\
\hline Mba & Rockadooie Ck, Washpool NP, NENSW & Feb-98 & 550 & Estimate \\
\hline Mba & Sharpes Ck, Barrington Tops NP, NENSW & Oct-96 & 500 & Count \\
\hline Mba & Sharpes Ck, Barrington Tops NP, NENSW & Oct-96 & 550 & Count \\
\hline Mba & Sharpes Ck, Barrington Tops NP, NENSW & Feb-00 & 130 & Estimate \\
\hline Mba & Sharpes Ck, Barrington Tops NP, NENSW & Feb-00 & 250 & Estimate \\
\hline Mba & Sharpes Ck, Barrington Tops NP, NENSW & Feb-00 & 550 & Estimate \\
\hline Mba & Frying Pan Ck, Chichester SF, NENSW & Nov-0 I & 824 & Count \\
\hline Mba & Gap Ck, Watagans NP, MENSW & Dec-95 & 230 & Count \\
\hline Mfa & Dalrymple Ck south branch, Main Range NP, SEQ & Nov-96 & |33| & Count \\
\hline Mfa & Yabbra Ck, Yabbra NP, NENSW & Jan-00 & 2005 & Count \\
\hline Mfa & Yabbra Ck, Yabbra NP, NENSW & Jan-00 & 1400 & Estimate \\
\hline Mfa & Yabbra Ck,Yabbra NP, NENSW & Jan-00 & 1210 & Estimate \\
\hline Mfa & Unnamed trib. Bat Cave Ck, Nightcap NP, NENSW & Sep-95 & 1200 & Count \\
\hline Mfa & Unnamed trib. Bat Cave Ck, Nightcap NP, NENSW & Sep-95 & 740 & Count \\
\hline Mfa & Unnamed trib. Bat Cave Ck, Nightcap NP, NENSW & Sep-95 & 2800 & Count \\
\hline Mfa & Unnamed trib. Bat Cave Ck, Nightcap NP, NENSW & Sep-95 & 1000 & Count \\
\hline Mfl & Dalrymple Ck south branch, Main Range NP, SEQ & Feb-97 & 1750 & Estimate \\
\hline $\mathrm{Mfl}$ & Dalrymple Ck south branch, Main Range NP, SEQ & Dec-97 & 900 & Count \\
\hline $\mathrm{Mfl}$ & Gap Ck West, Main Range NP, SEQ & Sep-96 & 966 & Count \\
\hline $\mathrm{Mfl}$ & Gap Ck West, Main Range NP, SEQ & Sep-96 & 1250 & Count \\
\hline Mfl & Gap Ck West, Main Range NP, SEQ & Sep-96 & 941 & Count \\
\hline $\mathrm{Mfl}$ & Gap Ck West, Main Range NP, SEQ & Oct-96 & 587 & Count \\
\hline $\mathrm{Mfl}$ & Gap Ck West, Main Range NP, SEQ & Dec-96 & 709 & Count \\
\hline $\mathrm{Mfl}$ & Gap Ck West, Main Range NP, SEQ & Mar-97 & 874 & Count \\
\hline $\mathrm{Mfl}$ & Gap Ck West, Main Range NP, SEQ & Jan-0 I & 798 & Count \\
\hline Mfl & Bundoomba Ck, Lamington NP, SEQ & Oct-96 & 800 & Estimate \\
\hline $\mathrm{Mfl}$ & Bundoomba Ck, Lamington NP, SEQ & Oct-96 & 200 & Estimate \\
\hline Mfl & Bundoomba Ck, Lamington NP, SEQ & Oct-96 & 500 & Estimate \\
\hline $\mathrm{Mfl}$ & Bundoomba Ck, Lamington NP, SEQ & Oct-96 & 300 & Estimate \\
\hline Mfl & Darraboola Ck, Lamington NP, SEQ & Oct-96 & 590 & Count \\
\hline $\mathrm{Mfl}$ & Tuntable Ck, Nightcap NP, NENSW & Mar-0I & 480 & Estimate \\
\hline Mfl & Tuntable Ck, Nightcap NP, NENSW & Mar-0I & 360 & Estimate \\
\hline $\mathrm{Mfl}$ & Tuntable Ck, Nightcap NP, NENSW & Apr-03 & 660 & Estimate \\
\hline Mfl & Tuntable Ck, Nightcap NP, NENSW & Aug-03 & 265 & Estimate \\
\hline Mfl & Tuntable Ck, Nightcap NP, NENSW & Aug-03 & 740 & Estimate \\
\hline Mfl & Tuntable Ck, Nightcap NP, NENSW & Sep-05 & 200 & Estimate \\
\hline
\end{tabular}




\begin{tabular}{lllll}
\hline Species & Location & Date & Number of eggs & Count or estimate \\
\hline Mfl & Yabbra Ck, Yabbra NP, NENSW & Feb-00 & 500 & Estimate \\
\hline Mfl & Tuntable Ck, Nightcap NP, NENSW & Sep-05 & 345 & Estimate \\
\hline Mfl & Tuntable Ck, Nightcap NP, NENSW & Sep-05 & 150 & Estimate \\
\hline Mfl & Tuntable Ck, Nightcap NP, NENSW & Sep-05 & 200 & Estimate \\
\hline Mfl & Tuntable Ck, Nightcap NP, NENSW & Feb-06 & 850 & Estimate \\
\hline Mfl & Tuntable Ck, Nightcap NP, NENSW & Feb-06 & 505 & Estimate \\
\hline Mfl & Tuntable Ck, Nightcap NP, NENSW & Aug-03 & 250 & Estimate \\
\hline Mfl & Tuntable Ck, Nightcap NP, NENSW & Aug-03 & 120 & Estimate \\
\hline Mfl & Tuntable Ck, Nightcap NP, NENSW & Sep-02 & 175 & Estimate \\
\hline Mfl & Tuntable Ck, Nightcap NP, NENSW & Apr-03 & 310 & Estimate \\
\hline Mit & Desert Ck, Washpool NP, NENSW & Nov-95 & 2200 & Count \\
\hline Mit & Bucca Bucca Ck, Orara East SF, NENSW & Jan-95 & 1660 & Count \\
\hline Mit & Bucca Bucca Ck, Orara East SF, NENSW & Jan-00 & 1890 & Count \\
\hline Mit & Bucca Bucca Ck, Orara East SF, NENSW & Feb-00 & 2200 & Count \\
\hline
\end{tabular}
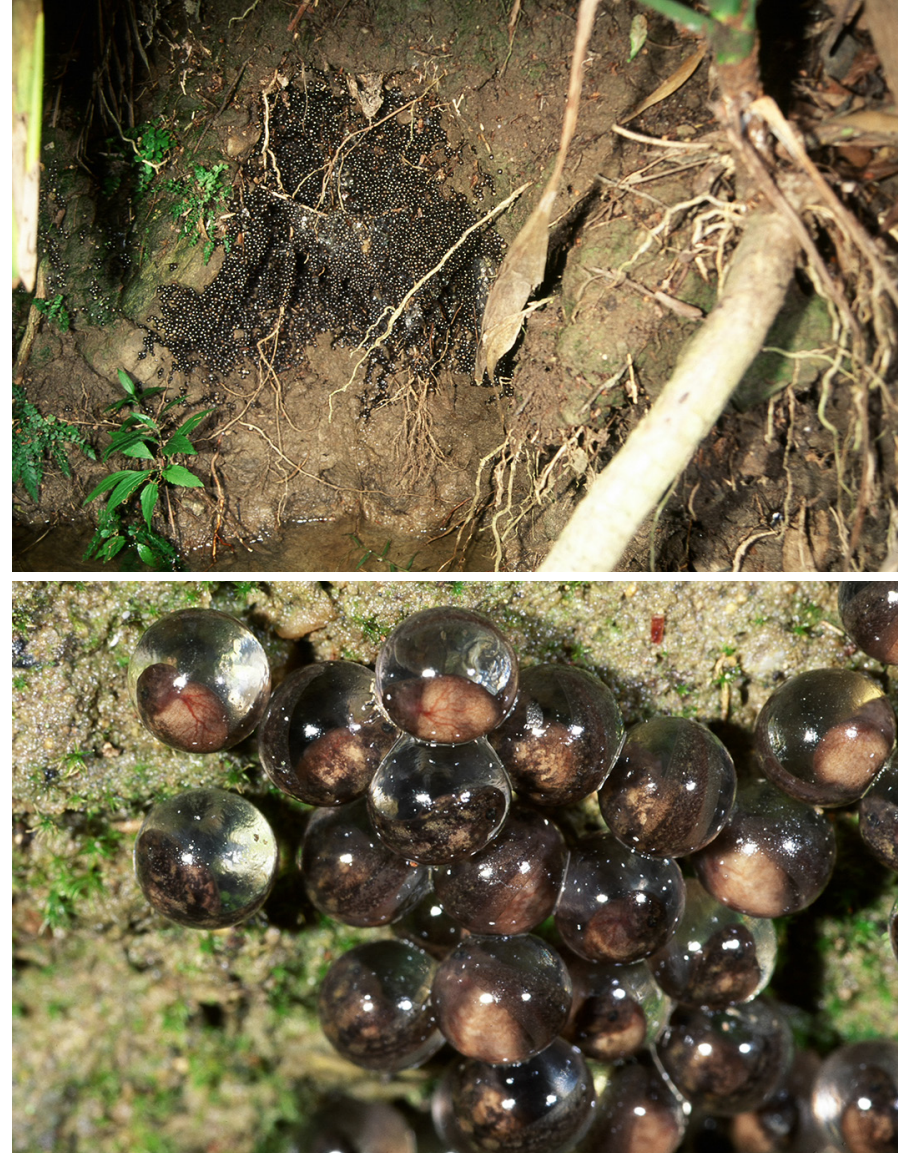

Figure 10. Mass spawning of Mixophyes fasciolatus, Jacky Ck D'Aguilar NP, SEQ, 7 Jan 1999.Top - oviposition site, showing multiple clutches, totalling many thousands of eggs, on a more or less vertical earthen stream bank. The paler area in the centre of the egg mass is rotting eggs. Bottom - close-up of the late stage eggs (stage 23-4) showing heavily pigmented tadpoles and highly vascularised yolk sacs. Photos, H.B. Hines.
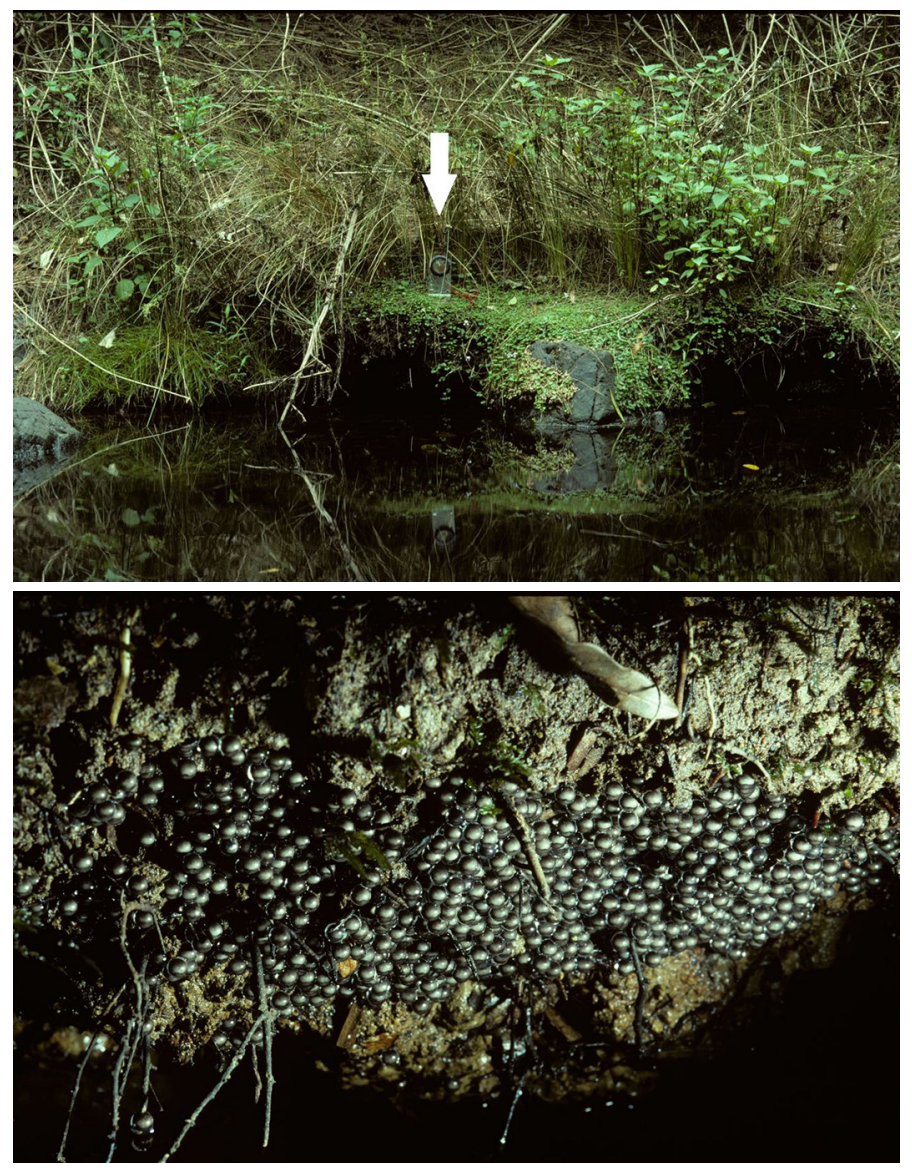

Figure II. Oviposition site and egg mass of Mixophyes iteratus, Desert Ck, Washpool NP, NENSW, Dec 1995. Top - oviposition site, eggs were laid onto the ceiling of the undercut stream bank immediately below the compass (indicated by the white arrow). Bottom - closeup of the eggs (stage 19) on the ceiling of the undercut stream bank. Photos, R. Knowles. 
Table 6. Diameter and development stage of Mixophyes eggs. Refer to Table 2 for additional locality details. Development stage as per Gosner (1960). SE = standard error of the mean. Species abbreviations as per Table 2.

It is our experience that measurements of egg diameters are affected by a number of factors such as the degree of hydration, method of measurement, as well in changes in the shape of the egg in the latter stages of development. These are field measurements taken using calipers, with the eggs on a solid substrate and are the diameter of the capsule (see Anstis 2002, p. 70).

\begin{tabular}{|c|c|c|c|c|c|c|}
\hline Species & Locality & Development stage & Mean & SE & Range & $\mathrm{n}$ \\
\hline Mfa & Kroombit Ck north branch, Kroombit Tops NP, SEQ & Late, $>20$ & 4.6 & 0.07 & $4.1-5.0$ & 13 \\
\hline Mfa & Bullocky's Knob pond, D'Aguilar NP, SEQ & Late, $>20$ & 5.7 & 0.13 & $5.4-6.1$ & 6 \\
\hline Mfa & Bullocky's Knob pond, D'Aguilar NP, SEQ & Early, $<5$ & 3.2 & 0.04 & $3.1-3.3$ & 6 \\
\hline Mfa & Dalrymple Ck south branch, Main Range NP, SEQ & Early, $<5$ & 2.6 & 0.06 & $2.2-3.0$ & 16 \\
\hline Mfa & Gap Ck West, Main Range NP, SEQ & Late, $>20$ & 4.7 & 0.10 & $4.3-4.9$ & 6 \\
\hline $\mathrm{Mfl}$ & Gap Ck West, Main Range NP, SEQ & Mid, $<12$ & 2.8 & 0.04 & $2.5-3.0$ & 10 \\
\hline Mfl & Gap Ck West, Main Range NP, SEQ & Early, $<5$ & 3.0 & 0.04 & $2.7-3.3$ & 17 \\
\hline $\mathrm{Mfl}$ & Bundoomba Ck, Lamington NP, SEQ & Late, $>20$ & 3.2 & 0.05 & $3.0-3.6$ & I I \\
\hline $\mathrm{Mfl}$ & Bundoomba Ck, Lamington NP, SEQ & Mid, 17-19 & 3.3 & 0.06 & $3.0-3.6$ & 9 \\
\hline $\mathrm{Mfl}$ & Brindle Ck, Border Ranges NP, NENSW & Early, $<5$ & 4.2 & 0.03 & $3.7-4.5$ & 50 \\
\hline
\end{tabular}
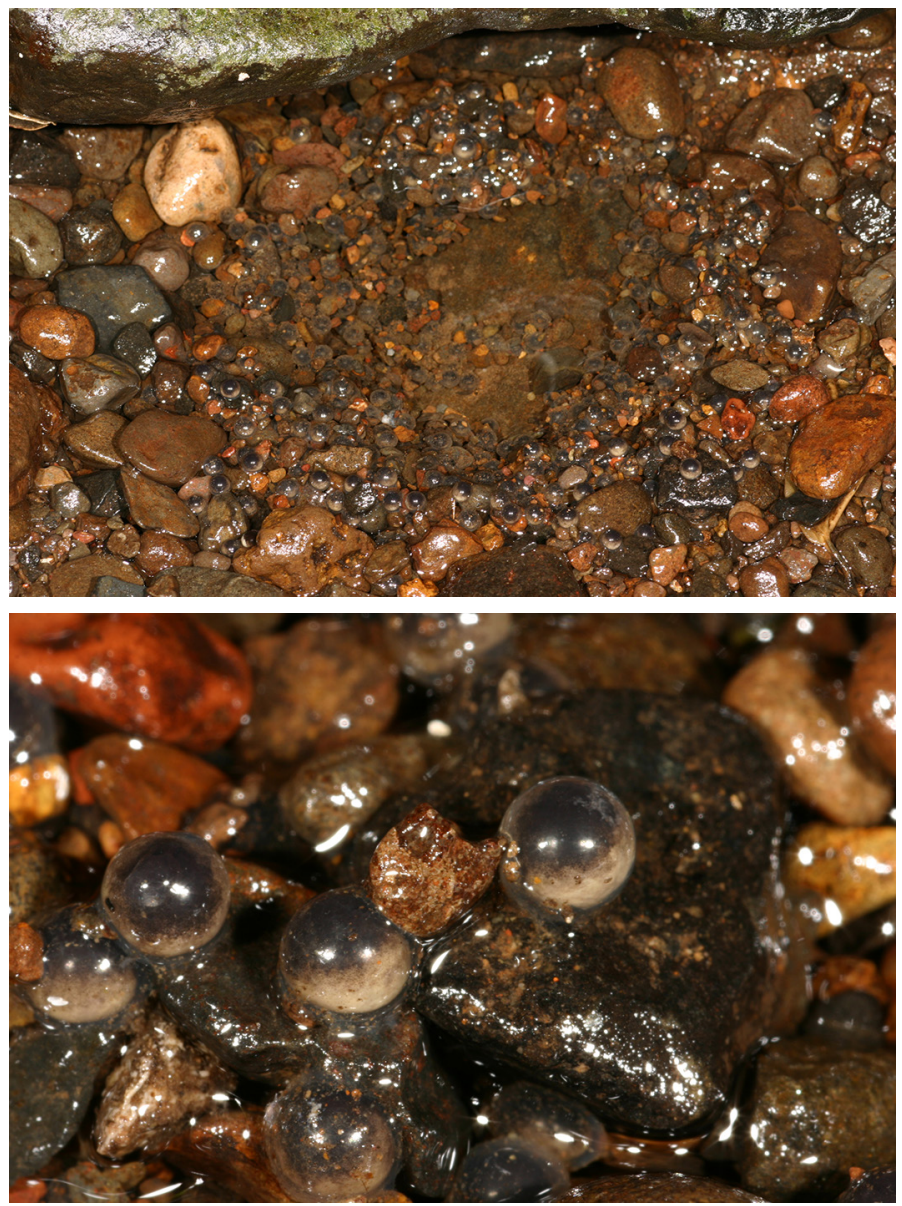

Figure 12. Nest and eggs of Mixophyes fleayi, Gap Ck West, Main Range NP, SEQ, 26 Oct 2004. Top - nest constructed in gravel in shallow, gently flowing water. Most eggs are packed into the gravel around the perimeter of the nest depression. Note the larger stone on the upstream side of the egg mass which probably provides some protection from higher stream flows. Bottom close-up of eggs, ( stage 9). Photos, H.B. Hines.
Egg masses of M. fleayi were typically laid in shallow, gently flowing water of glides and riffles of higher order streams (mostly stream order two and three - Table 2). Egg masses tended to be laid in the centre of the stream (see Figure 18) and were only very rarely seen towards or at the stream margin. This bias in nest site preference resulted in a very patchy distribution of egg masses along streams with some streams having very limited suitable oviposition microhabitat. The form of the egg mass varied depending upon the substrate and stream morphology. The vast majority of egg masses were laid in a nest depression made in the stream bed by the female whilst in amplexus - formed by her shuffling her hind limbs amongst the substrate, whilst spinning around (step three in Ovipositional Process 2 described above). The resultant nest was more or less circular where the substrate was fine and homogenous, such as sand or gravel (Figure 12). More irregular substrates (leaf litter, coarse gravel) or less homogeneous substrates resulted in less symmetrical nests (Figure 13). For recently laid (i.e. Gosner stage <10) M. fleayi egg masses at Gap Ck West, Main Range NP, SEQ, the mean depth of water in the centre of the nest depression was $34 \mathrm{~mm}(\mathrm{n}=$ $37, \mathrm{SE}=1.5$, range $=15-45 \mathrm{~mm}$ ). In larger streams or steeper sections of streams, egg masses were often laid immediately downstream of a larger stone, presumably providing some protection from higher flows (Figure 12).

Some streams that lacked sandy or gravelly riffles or glides had suitable oviposition sites in sections where shallow water flowed gently over wide areas of exposed bedrock in the stream bed. Oviposition was not observed but at least 10 egg masses were found in these situations, at three sites. Eggs were laid directly onto the bed rock as a single layer, or up to a few layers deep (Figure 15). In these cases the eggs adhered strongly to the bedrock such that they would be capable of withstanding substantially increased flows of water. We refer to this as Ovipositional Process $2 \mathrm{~B}$ to distinguish it from the more frequently encountered process described above (which we refer 

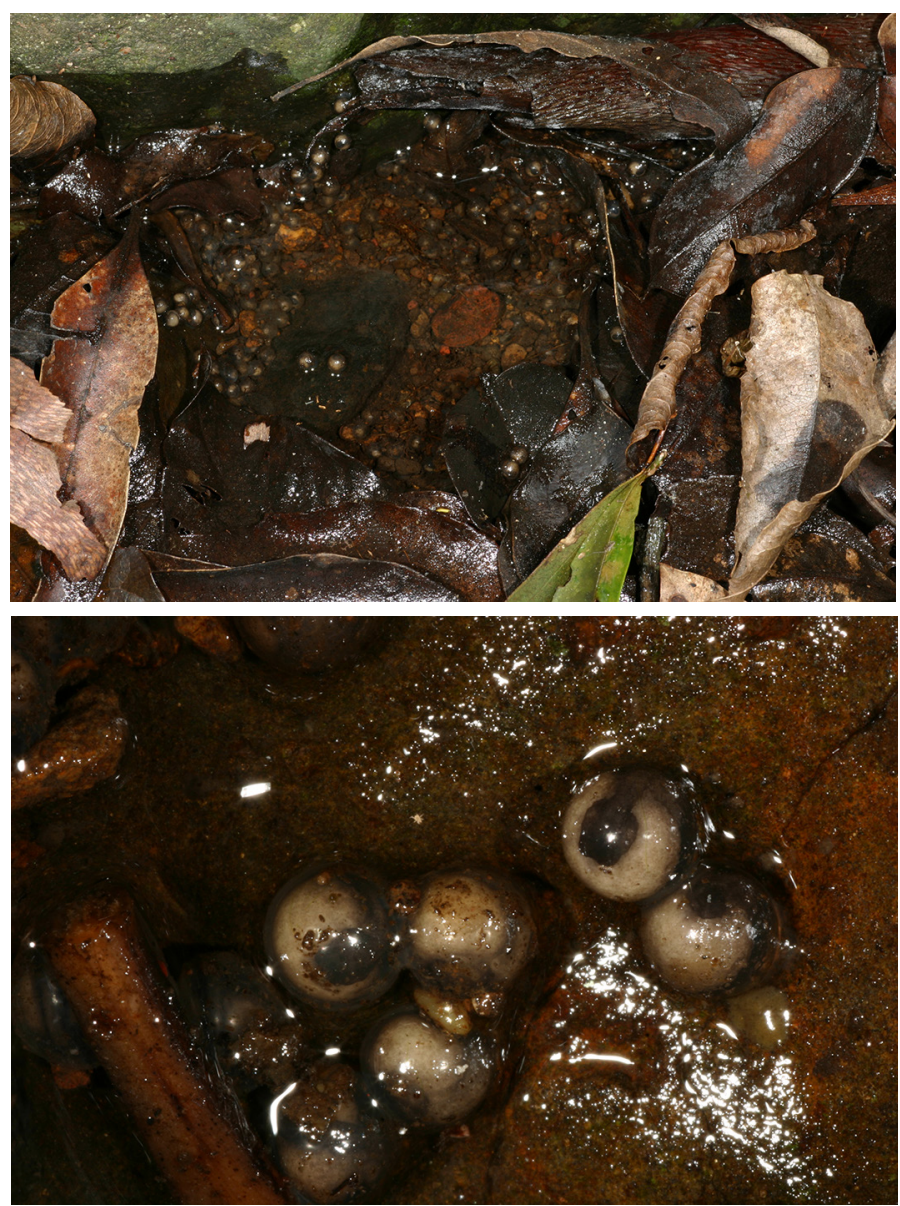

Figure 13. Nest and eggs of Mixophyes fleayi, Gap CkWest, Main Range NP, SEQ, I 5 Mar 2007. Top - nest constructed in leaf litter and gravel in shallow, gently flowing water. Most eggs are packed into the litter and gravel around the perimeter of the nest depression. Bottom - close-up of eggs ( stage 18). Photos, H.B. Hines.

to as Ovipositional Process 2A). At some breeding sites Process 2B formed the majority of egg masses observed (e.g. parts of Bundoomba Ck, Lamington NP, SEQ). However even at streams where there were substantial areas of gravelly riffles and glides, occasional egg masses were observed on bedrock (e.g. one of 413 egg masses at Gap Ck West, Main Range NP, SEQ). These observations show that Ovipositional Processes $2 \mathrm{~A}$ and $2 \mathrm{~B}$ are not particular to certain populations of M. fleayi but are likely to be flexible responses within populations and potentially individuals, presumably to exploit available substrate with suitable hydrology.

In addition to the M. fleayi egg masses listed in Tables 2 and 4 we occasionally observed egg masses with very low numbers of eggs (e.g. 10-15 eggs) or scattered over larger areas and not of the form of typical egg masses. As with M. fasciolatus this may have been a result of the amplectant pair choosing an unsuitable oviposition site and subsequently moving, harassment by other males, and or disturbance by nocturnal predators. At times at Gap Ck West, Main Range NP, SEQ large numbers of male M. fleayi congregated on the gravel banks used for oviposition which resulted in many physical interactions between calling males and between males and amplectant pairs
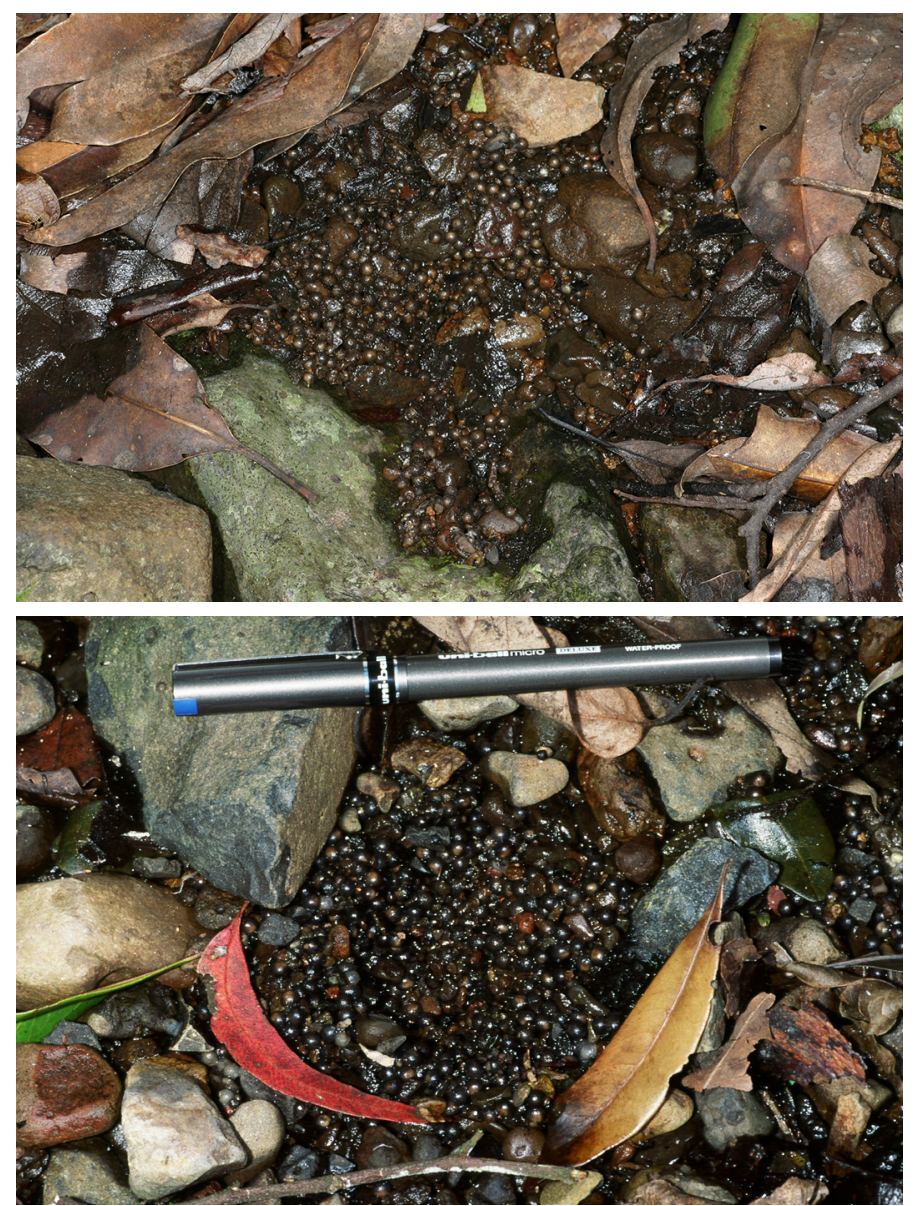

Figure 14. Egg masses of Mixophyes fleayi, following falls in water level of the stream, Gap CkWest, Main Range NP, SEQ, top - 15 Mar 2007, bottom - 22 Oct 1998. In both cases the eggs remained moist and viable. Photos, H.B. Hines.

(see Figures 7 and 9 of Stratford et al. 2010). Amplectant males were observed on at least two occasions to fend off other males with their hind limbs. Rough-scaled snakes Tropidechis carinatus were also frequently observed at oviposition sites and one was observed attempting to ingest a female M. fleayi (Figure 17).

Calling activity (O'Reilly and Hines, 2002, Stratford et al. 2010) and oviposition (Hines unpublished data) in M. fleayi (and presumably M. balbus) are strongly linked to stream flow and season. Peak breeding activity occurs as the stream falls back to basal flow following a period of higher flow, from spring through summer to early autumn. Depending upon the temperature of the water, egg development can take up to several weeks (Hines unpublished data). During the period of development the stream level sometimes dropped causing the nest depression to drain. Eggs appeared to remain viable as long as the substrate was moist (even if no surface water was visible) (Figure 14). On a number of occasions recently hatched tadpoles were found alive, sheltering within the moist substrate, with only their tails sticking out of the gravel. However, on several occasions desiccated eggs and or tadpoles were observed when the substrate dried out. At other times the stream level rose 
following oviposition and often in these circumstances large conspecific tadpoles or tadpoles of M. fasciolatus were observed foraging on the eggs (this was observed at eight sites). Large Mixophyes tadpoles usually inhabited much deeper water (pools) than that used by M. fleayi for oviposition (glides and riffles). If the stream remained near basal flow hatchling tadpoles were observed within the nest depression (Figure 16), where they appeared to eat the remains of egg capsules, before moving out to the surrounding stream.

Many egg masses of M. fleayi contained a small proportion of rotting eggs, presumably unfertilised or unviable eggs that succumbed to aquatic fungi. Occasionally entire egg masses were affected, for example on 05 Feb 2002 at Gap Ck West, Main Range NP, SEQ (Table 2) five eggs masses were rotten, most likely due to desiccation followed by rewetting from rainfall.

\section{Potential egg predators}

Most streams where M. fleayi occur support a low species richness of fish. East of the Great Dividing Range eels (southern shortfin eel Anguilla australis and or longfin eel A. reinhardtii) are present at low density at all altitudes. At lower altitudes (e.g. Tallebudgera Ck, near Springbrook NP, SEQ - Table 2) additional species, such as Cox gudgeon Gobiomorphus coxii, are present. Eels are absent from streams running west of the Great Dividing Range, but mountain galaxias Galaxias olidus, are often abundant, and the freshwater catfish Tandanus tandanus, was also present at one site (Condamine R., near Main Range NP, SEQ - Table 2). In contrast to our observations of tadpole predation, we never saw fish attacking egg masses of M. fleayi. On the morning of 08 Mar 1997 at Gap Ck West, Main Range NP, SEQ (Table 2) some M. fleayi eggs were taken from an egg mass and offered to G. olidus in a nearby pool. The fish immediately attacked the small clumps of eggs, with larger fish appearing capable of ingesting several eggs at a time. Small fish had problems ingesting single eggs but rapidly ate smaller egg fragments created by the bigger fish. This was repeated with similar results for a second egg mass about $800 \mathrm{~m}$ further upstream.

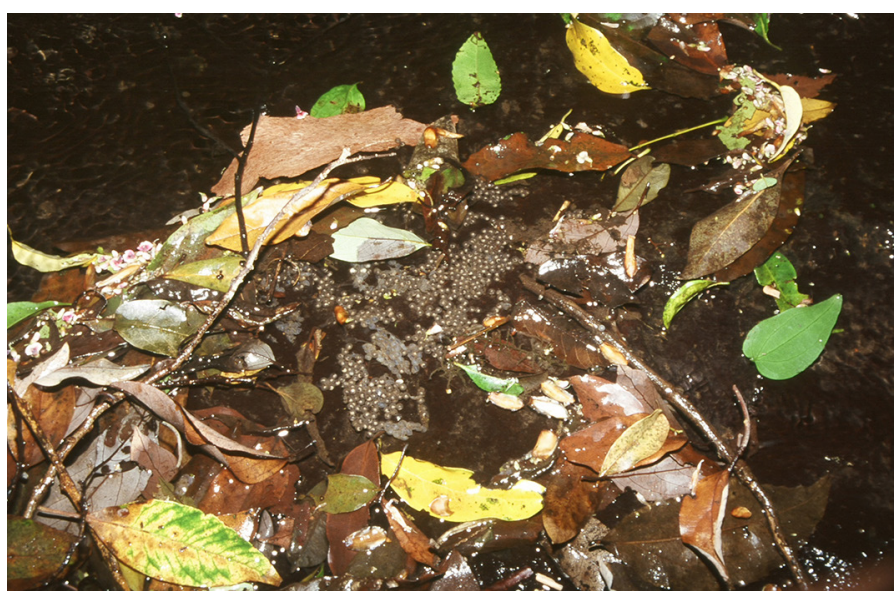

Figure I5. Egg mass ( stage 19) of Mixophyes fleayi, laid directly onto bed rock (Oviposition Process 2B), under very shallow gently flowing water, Bundoomba $\mathrm{Ck}$, Lamington NP, SEQ, I 3 Dec 1999. Photo, H.B. Hines.
In contrast the lower order streams that often form the habitat for M. fasciolatus and in particular M. iteratus (e.g. Mary, Stanley and Coomera Rivers, SEQ) are rich in fish species, including large predatory species such as gudgeons (Gobiomorphus spp., Mogurnda adspersa), eels (Anguilla spp.), catfish (T. tandanus), Australian bass (Macquaria novemaculeata) and cod (Maccullochella spp.) (Pusey, Kennard and Arthington 2004), likely to find Mixophyes eggs highly palatable. While we have not tested this assumption widely, on 18 Nov 1996 a small number of M. fasciolatus eggs were offered to G. olidus that were living in the pool immediately below an oviposition site, at Dalrymple $\mathrm{Ck}$ south branch, Main Range NP, SEQ (Table 2). The eggs were immediately attacked and consumed by the fish.

Many species of crayfish co-occur with Mixophyes species, in particular from the genus Euastacus. The diet of Australian crayfish is poorly known but they are considered polytrophic (Coughran and Furse in press). Euastacus in the laboratory feed on a range of foods, including meat, and in the field they are readily attracted to protein-based baits (e.g. Furse 2010). Euastacus sulcatus is a large species that forages widely along streams and adjoining forests, by day and by night (Coughran 2013) and is common at many M. fleayi breeding sites. For example it is abundant at Gap Ck West, Main Range NP, SEQ (Table 2) where we have observed many egg masses in the stream bed (413) over a range of years, seasons, times of day and climatic conditions. On several occasions we observed Euastacus in close proximity to $\mathrm{M}$. fleayi egg masses but surprisingly we did not see evidence of egg predation.

\section{Discussion}

Oviposition has now been observed in the wild for M. balbus, M. fleayi, M. fasciolatus and M. iteratus (our observations; Lewis 2000) and M. coggeri (Hoskin 2010). The natural egg deposition sites and the form of egg masses for all Australian species of Mixophyes are now known. Within the genus there are two markedly different ovipositional processes and resultant egg mass structures.

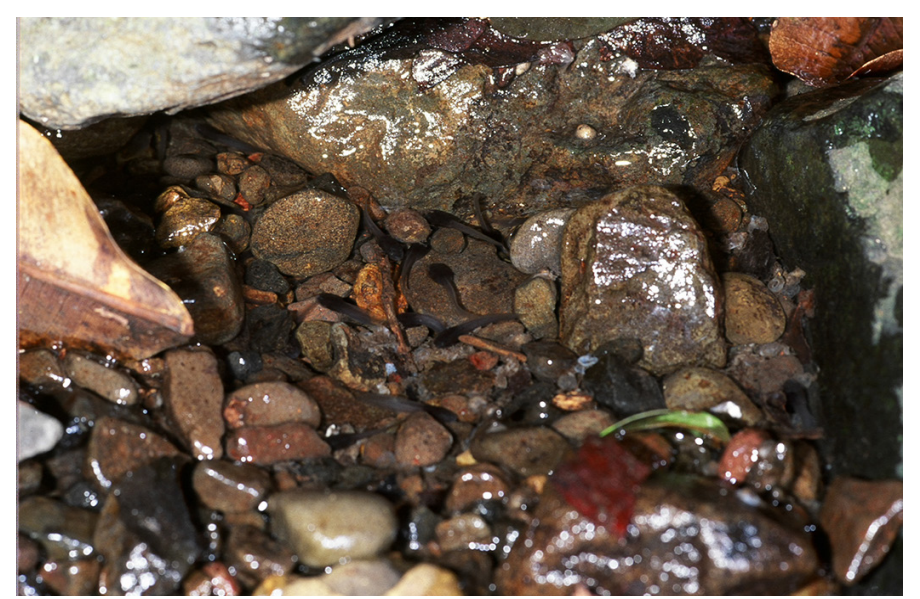

Figure 16. Hatchling Mixophyes fleayi tadpoles (stage 25) in the water filled nest depression, Gap Ck West, Main Range NP, SEQ, 12 Nov 1998. Photo, H.B. Hines. 
Ovipositional Process 1 involves a floating amplectant pair propelling eggs out of the water, resulting in an egg mass on the sides of the stream bank or on the ceiling of an undercut stream bank, and is now known from M. fasciolatus and M. iteratus (observations presented here), M. coggeri (Hoskin 2010, Anstis 2013) and M. carbinensis and M. schevilli (Anstis 2013). Ovipositional Process 2 involves an amplectant pair laying eggs in shallow running water, either in a nest depression constructed within sand, gravel or detritus, or pasted directly onto bedrock, both within the stream bed, and is now known from M. fleayi and M. balbus (observations presented here; Lewis 2000). Oviposition and spawn of M. hihihorlo, a species endemic to Papua New Guinea, remains unknown.

Our use of the term egg mass is equivalent to the concept of a 'group' of eggs sensu Altig and McDiarmid (2007), such that a group can comprise eggs from one or more bouts of egg laying and that one or more groups may make up the clutch. Altig and McDiarmid (2007) define a clutch as the total number of eggs deposited per ovulation event. The ovipositional mode (Altig and McDiarmid 2007) of each group of Mixophyes eggs is an adherent clump, i.e. a multilayered stack of eggs that lack a common, surrounding surface or matrix, with interstices among eggs and with adjacent eggs adherent. A clutch of Mixophyes eggs is therefore one or more adherent clumps, either deposited aquatically or terrestrially. Consequently the egg masses we observed may at times have been part of a clutch, the entire clutch or include eggs from multiple clutches (different pairs of frogs depositing eggs within a short timespan). This is likely to explain the wide ranges in observed counts of eggs in egg masses in the field (Table 5) and our observations of scattered eggs or egg masses with very low counts. This is further supported by Lewis' (2000) observation of a pair of M. balbus that constructed ten nest depressions, of which eight contained eggs. It may also explain discrepancies with high gonadal counts of eggs, for example 4184 eggs for a museum specimen of M. iteratus (Hero and Fickling 1996) compared with the four egg masses we counted for this species (range 1660-2200).

The observations of ovipositing, depositional sites and egg masses show that there are three reproductive modes (sensu Haddad and Prado 2005) in the genus: mode 2 eggs and exotrophic tadpoles in lotic water (Ovipositional Process $2 \mathrm{~B}$ of $\mathrm{M}$. fleayi), mode 4 - eggs and early larval stages in constructed basins, subsequent to flooding exotrophic tadpoles in streams (Ovipositional Process 2A of M. balbus and M. fleayi), and mode 18 - terrestrial eggs above water, exotrophic tadpoles move to water (Ovipositional Process 1 of M. carbinensis, M. coggeri, M. fasciolatus, M. iteratus and M. schevilli). Furthermore, reproductive mode 18 within Mixophyes, was mostly in stream habitats although M. fasciolatus also used ponds.

These modes of reproduction are likely to be adaptations to avoid loss of eggs to aquatic predators such as odonates, beetles, fish and tadpoles, whilst maintaining egg moisture and oxygen supply (Magnusson and Hero 1991; Duellman and Trueb 1994; Resetarits 1996; Haddad and Prado 2005; Malone 2004, Altig and McDiarmid 2007). Our

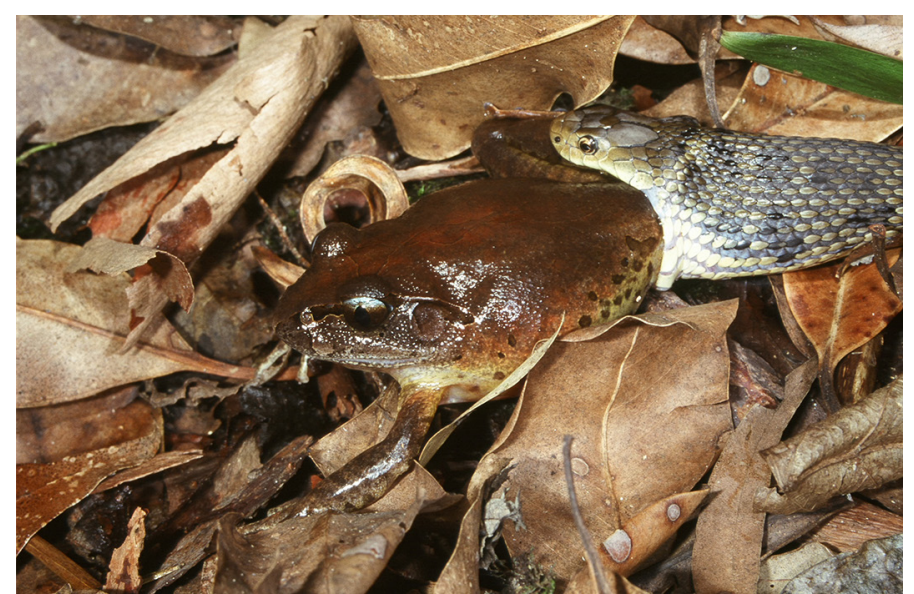

Figure 17. Female Mixophyes fleayi being ingested by a rough-scaled snake Tropidechis carinatus, Gap Ck West, Main Range NP, SEQ, 06 Mar 2002. Photo, H.B. Hines.

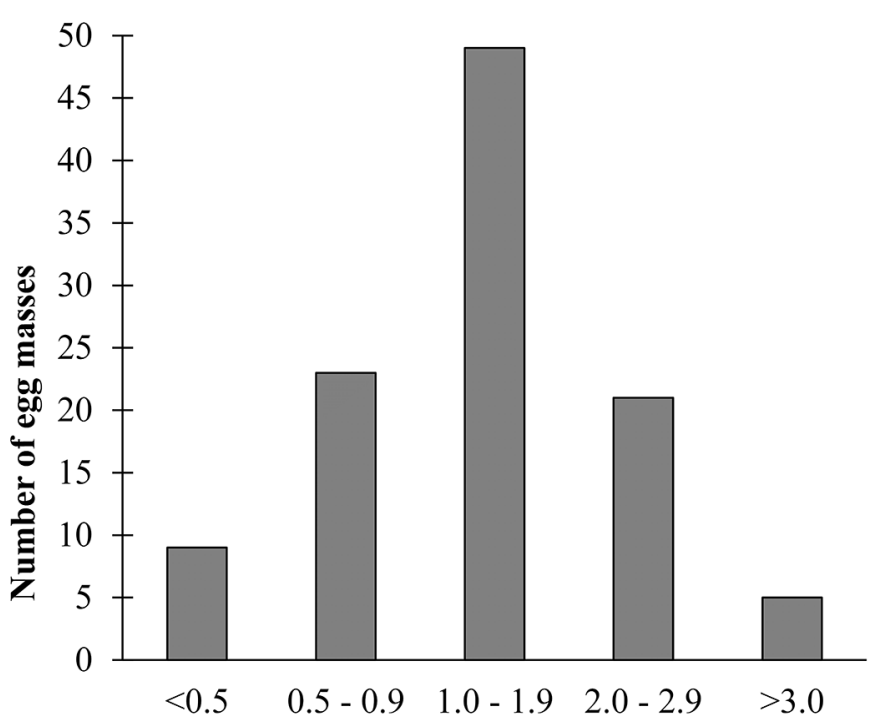

Distance to nearest stream margin (m)

Figure 18. Distance of Mixophyes fleayi egg masses from the nearest stream margin $(n=107)$, from four sites in Main Range and Lamington National Parks, SEQ. The distance was the right angle distance from the egg mass (laid in the stream bed) to the nearest wetted margin of the stream.

observations, of tadpoles feeding on egg masses of M. fleayi and of sympatric native fish consuming M. fasciolatus and M. fleayi eggs offered to them, support this hypothesis. Depositing eggs out of water or in shallow water is not without risks as both are prone to desiccation and terrestrial predators (e.g. Richards 1993). Typically the sites used in mode 18 (i.e. eggs laid out of water) are sheltered from direct sunlight, either as a consequence of being deposited behind overhanging vegetation (Figures 7-9), under a dense forest canopy (e.g. rainforest) or under an embankment, rock or other structure (Figures 8 and 11). Also the eggs are within a short distance of the water and in situations where the humidity is high. In M. balbus and M. fleayi (modes 2 and 4) a drop in stream flow can result in egg masses and/or hatchling tadpoles being stranded 
without free water. Our experience with M. fleayi suggests that eggs or hatchling tadpoles can survive as long as the substrate remains moist (Figure 14) and the oviposition site receives little or no direct sunlight. Furthermore, we have observed hatchling tadpoles of $\mathrm{M}$. fleayi seeking refuge by burrowing into the moist substrate at the oviposition site.

Reproductive mode 4 is only known from a few hylids from central and southern America, e.g. Smilisca sordida and the Hypsiboas semilineatus species group (Faivovich et al. 2005), four Asian ranids and in the Australian hylid Litoria jungguy (Richards, 1993; using the name L. lesueuri, see Donnellan and Mahony 2004) (Malone 2004 and references therein). Richards (1993) proposed that the evolution of nest construction in L. jungguy was in response to a fine, mobile substrate on which egg deposition was problematic without a depression to protect the egg mass from the stream current. This scenario is unlikely in Mixophyes as the substrate is usually much more heterogeneous, coarser and stable and the eggs are mixed into the substrate and bind firmly to it and each other, rather than the gelatinous egg mass of L. jungguy which is not incorporated into the substrate. A third hypothesis for the functional significance of nest construction is that it results in elevated temperatures and hence reduced developmental times for eggs within the depression (Richards 1993 and references therein; Malone 2006). Again this is unlikely in Mixophyes as nests typically have stream water very gently percolating through them. However additional studies are required to test these hypotheses.

Foamy egg masses are a feature of several limnodynastid genera where eggs are placed in water or in burrows, and Seymour, Mahony and Knowles (1995) argue that the function of the foam is to facilitate gas exchange. Gas exchange would not appear to be a problem for the eggs of Mixophyes species laid out of water because they are typically exposed to the air on at least part of their surface (Figures 6-11), and the sites have high humidity which is essential to keep the egg capsule moist so that oxygen can diffuse into the egg. For the species using modes 2 and 4, eggs are placed in cool, shallow, gently flowing water, where oxygenation is likely to be high. If the stream level drops, eggs of these species are exposed to the air (Figure 14) but while they remain moist oxygen diffusion presumably will be high.

Previous accounts of oviposition and egg masses were based on either very low numbers of observations in the field or from captive animals, and sometimes lacked sufficient detail or clarity, or assumed similar ovipositional processes for all Mixophyes species. Our observations fill a number of knowledge gaps, thus enabling some clarification of contradictory or potentially misleading statements in the literature, particularly in regard to oviposition site. In the following section we address some of these major discrepancies, supported by our observations.

Straughan (1966 unpubl.) and Robinson (1993) imply that M. fasciolatus eggs are laid by the amplectant pair sitting out of water. The six amplectant pairs we observed laid eggs whilst floating in water. In addition the vast majority of the 79 egg masses we observed of this species were in situations where it would have been impossible for the amplectant pair to lay eggs unless they were floating in water (i.e. laid on vertical banks or beneath undercut banks/overhangs). Furthermore, Straughan's observations (and later cited by Martin 1967) of M. fasciolatus eggs being laid in loose detritus along banks appears atypical, as most of our observations were of eggs on near vertical surfaces or beneath overhangs. Our data do not concur with statements by Straughan (1966 unpubl.), Barker and Grigg (1977) or Barker, Tyler and Grigg (1995) that when larvae hatch they are washed by rain or flood into the water body. Most egg masses we saw were protected from rain or run-off, except in extreme conditions, and eggs were firmly attached to the substrate and or each other. We observed tadpoles hatching by wriggling strongly and rupturing the egg capsule and dropping or wriggling down to the water below, as documented in captivity by Marantelli (1995).

Hoser's (1989) statement that M. balbus lays eggs on vegetation adjacent to streams is contrary to our observations of $10 \mathrm{M}$. balbus egg masses from four sites, and the observations of Lewis (2000) at another site. We have only observed M. balbus and M. fleayi using Ovipositional Process 2, where eggs are laid in shallow running water in the stream bed ( $n=627$ for the latter). Occasionally we saw M. fasciolatus eggs attached to vegetation overhanging an oviposition site, but in these cases most eggs were attached to the substrate of the bank (e.g. soil, rock, root mass).

Ovipositional Process 2 has only been recognised in Mixophyes since the late 1990s (Knowles et al. 1998 unpubl.; Lewis 2000). Consequently much of the previous literature on oviposition and spawn of M. balbus and M. fleayi has largely been incorrect, assuming egg laying to be the same as for M. fasciolatus or based on atypical or poorly documented observations (Watson and Martin 1973, Barker and Grigg 1977, Robinson 1993, Tyler 1994, Barker, Tyler and Grigg 1995). Most intriguing is the account of eggs presumed to be those of M. fleayi by Corben and Ingram (1987) as being "found under a rock about $30 \mathrm{~cm}$ from water and attended by an adult frog". We have observed oviposition 11 times in M. fleayi (always in shallow running water in the stream bed) and have observed in excess of 600 egg masses from 19 sites across the geographical and altitudinal distribution of this species and have never seen eggs in such a situation. The only occasions adult frogs were in association with eggs was during amplexus, or rarely a female sitting in the nest depression during daylight hours, presumably following oviposition. However, males often called from positions in the stream bed, on top or near egg masses but with no indication of being "in attendance" of the egg mass. Corben and Ingram (1987) also described the eggs as resembling Pseudophryne, but the capsules were much larger. While capsule diameter varies with stage of development and degree of hydration, our measurements of eggs of varying developmental stage from five M. fleayi egg masses from three sites (Table 6), showed capsule diameter ranging from 2.5 to $4.5 \mathrm{~mm}$. The only Pseudophryne species that we have observed in the catchments of sites occupied by M. fleayi is P. coriacea 
which has a capsule diameter ranging up to $5.17 \mathrm{~mm}$ when hydrated (Anstis 2002), somewhat larger than we observed in M. fleayi and most other Mixophyes eggs (Table 6). Our observations suggest that it is more likely that an adult M. fleayi was sheltering under or beside a rock which coincidentally was the oviposition site of a Pseudophryne species.

\section{Phylogenetic significance}

The phylogenetic relationships and familial placement of Mixophyes within Myobatrachoidea (Myobatrachidae + Limnodynastidae) remain unresolved. Older, mainly morphology based studies, placed this genus within Limnodynastidae (e.g. Lynch 1973; Heyer and Liem 1976; Ford and Cannatella 1993; Davies 2003a). Limnodynastidae are united by fusion of the first two vertebrae (atlas and axis) whereas these vertebrae are free in all Myobatrachidae, including Mixophyes and Rheobatrachus (Lynch 1973; Heyer and Liem 1976; Davies 2003a). Horton (1982) and Donnellan, Mahony and Davies (1990) reported that the relatively simple arrangement of the genioglossus muscle of Mixophyes was distinct both from Limnodynastidae, and other Myobatrachidae, with the exception of Rheobatrachus (which differs in its fused tongue). By contrast, Ford and Cannatella (1993) suggested that connection between the $\mathrm{m}$. submentalis and $\mathrm{m}$. intermandibularis was a morphological synapomorphy of the Limnodynastidae, including Mixophyes. More recent DNA based analyses provide equivocal support, either for an association with Limnodynastidae (Roelants et al. 2007) or with Myobatrachidae (e.g.; Frost et al. 2006; Pyron and Wiens 2011). There is general agreement that Mixophyes is a highly differentiated lineage (Heyer and Liem 1976), with time-calibrated molecular phylogenies estimating divergence from other living relatives in the late Cretaceous, around 85 million years ago (mya), compared with a maximum of 70 mya among other Myobatrachidae and 55 mya among Limnodynastidae, excluding the similarly problematic Rheobatrachus, with estimated divergence around 90 mya from other Myobatrachoidea (Pyron 2014; Roelants et al. 2007).

The reproductive behaviour, egg mass and larval morphology in Mixophyes add to this picture of distinctness. All genera of Limnodynastidae (sensu Frost et al. 2006) have foamy egg masses, except for the desert-adapted Notaden and Neobatrachus, whereas Myobatrachidae (sensu Frost et al. 2006), including Mixophyes and Rheobatrachus, do not have foamy egg masses. Anstis (2013), however, states that the embryos and larvae of Mixophyes share close similarities with the family Limnodynastidae, with embryos having external gills and tadpoles with very similar oral disc and body form. External gills are absent in all other Myobatrachidae (sensu Frost et al. 2006) except Rheobatrachus (Anstis 2013). The position of amplexus in frogs is an evolutionarily conservative character, with shifts among related genera generally associated with changes in oviposition behaviour and sexual dimorphism (Wells 2007). Mixophyes has axillary amplexus, unlike other Myobatrachidae genera, which have inguinal amplexus (Anstis 2013). The functional significance of amplexus position is unclear, but Wells (2007) suggests that axillary amplexus allows fertilization of larger batches of eggs and a reduced oviposition period. There are few comparative data, however, on oviposition period in Myobatrachoids and the form of amplexus is not known from several genera (e.g., Arenophryne, Metacrinia, Myobatrachus, Rheobatrachus) (Anstis 2013). Surprisingly, considering the diversity of reproductive biology, there is little differentiation in sperm morphology between Mixophyes and limnodynastid frogs (Lee and Jamieson 1992).

The two ovipositional processes in Mixophyes reveal that different adaptive strategies have evolved within the genus despite similarities in morphology. Molecular phylogenetic analyses indicate that M. balbus and M. fleayi are sister taxa (Donnellan et al. 1990) and it is likely therefore, that Ovipositional Process 2, with egg masses in shallow running water, is a shared character. Similarly, Ovipositional Process 1, with eggs deposited out of water, unites the other members of the genus which form a sister clade (Donnellan et al. 1990). The only member of the genus for which oviposition is unknown is the enigmatic M. hihihorlo from Papua New Guinea which is a sister lineage to the Australian species in molecular phylogenetic studies (Donnellan et al. 1990). Without outgroup analysis, it is not possible to determine which of the ovipositional processes observed may represent the ancestral and which the derived state, and this may be assisted with observation of the mode in M. hihihorlo. Alternatively, it is possible that both processes are derived, as reproductive strategies are highly diverse within Myobatrachidae (sensu Frost et al. 2006) (Davies 2003b). There are no other members of the family Myobatrachidae that show either of these ovipositional processes. It is likely that, as with other aspects of reproductive strategy, ovipositional process is a character that is open to ecological selection and is not particularly useful for phylogenetic reconstructions beyond the genus level.

\section{Implications for conservation management}

Several management issues arise from the observations of oviposition in the barred frogs. The four species of Mixophyes which use Oviposition Process 1, M. carbinensis, M. coggeri, M. fasciolatus, M. iteratus and M. schevilli require undercut, overhanging or near vertical stream banks for egg deposition. The formation and retention of these structures is dependent upon or strongly influenced by the root masses of riparian vegetation (e.g. Beschta and Platts 1986; Cummins 1986; Treadwell, Koehn, and Bunn 1999; Pusey and Arthington 2003). Consequently, loss of this vegetation through clearing, logging, grazing, trampling (by stock and or humans) or rooting by feral pigs has the potential to reduce availability of oviposition sites. The presence of vegetation overhanging the stream bank/oviposition site is likely to protect eggs from sunlight and desiccation. Erosion resulting from trampling of stream banks by cattle and horses or loss of riparian vegetation as well as altered flow regimes from impoundments, infrastructure development (e.g. bridge 
pylons) or changes in catchment hydrology (e.g. broad scale clearing) will reduce availability of oviposition sites.

Mixophyes balbus and M. fleayi, which use Oviposition Process 2, are species of conservation concern (Table 1). These species usually place egg masses in gently flowing, shallow riffles. As riffles have lower banks than the surrounding stream sections stock tend to use them to access or cross the stream. Due to the presence of shallow water, riffles are often used for road, bike, horse-riding and walking track crossings. We observed trampling of Mixophyes fleayi egg masses by stock and or humans at several sites, as well as fouling and damage to potential oviposition sites by cattle. Where there are populations of M. balbus or M. fleayi, stream crossings (for people, stock and vehicles) should avoid riffles. Road crossings, forestry activities, grazing and land clearing can increase sediment in streams (Parris and Norton 1997; Gillespie and Hines 1999). Higher sediment loads may reduce the availability or quality of oviposition sites through filling of interstitial spaces in the stream bed and blanketing substrates, resulting in increased mortality of eggs from predation, desiccation or flooding (Gillespie and Hines 1999). The weed mistflower Ageratina riparia is now well established across the range of $M$. fleayi, particularly at riffles with more open canopy cover. This herbaceous weed forms dense stands within the stream bed and its abundant roots bind the substrate tightly, possibly reducing oviposition site availability or quality. Further research on the potential impacts of this weed on Mixophyes species is required. Control activities in riffles should avoid the use of chemicals and be done in winter to avoid the extended breeding season of these two species.

\section{Acknowledgments}

We would like to thank Earthwatch for providing volunteers for some of the field work. Thanks also to the artist of figure 3, Greg Hancox. Field work was carried out under various permits issued by NSW NPWS and State Forests of NSW and with the permission of the Animal Care and Ethics Committees of The University of Newcastle, Southern Cross University and Queensland
Parks and Wildlife Service. Many people assisted in the field, with particular thanks to Mani Bergout, Adrian Borsboom, Brent Dadds, Naomi Doak, Brett Manning, Edward Meyer and Woo O'Reilly. Marion Anstis and an anonymous reviewer provided comments that improved the manuscript.

\section{References}

Altig, R. and McDiarmid, R.W. 2007. Morphological diversity and evolution of egg and clutch structure in amphibians. Herpetological Monographs 21: 1-32. http://dx.doi. org/10.1655/06-005.1

Anstis, M. 2002. Tadpoles of South-eastern Australia - a Guide with Keys. New Holland Publishers, Sydney, Australia.

Anstis, M. 2013. Tadpoles and Frogs of Australia. CSIRO Publishing, Melbourne.

Banks, C., Birkett, J., Young, S., Vincent, M. and Hawkes, T. 2003. Breeding and management of the great barred frog, Mixophyes fasciolatus, at Melbourne Zoo. Herpetofauna 33: 2-12.

Barker, J. and Grigg, G.C. 1977. A Field Guide to Australian Frogs. Rigby Limited, Australia.

Barker, J., Grigg, G.C. and Tyler, M.J. 1995. A Field Guide to Australian Frogs. Surrey Beatty and Sons, Chipping Norton, NSW.

Beschta, R.L. and Platts, W.S. 1986. Morphological features of small streams: significance and function. Water Resources Bulletin 22: 370-379. http://dx.doi.org/10.1111/j.1752-1688.1986. tb01891.x

Corben, C.J. and Ingram, G.J. 1987. A new barred river frog (Myobatrachidae: Mixophyes). Memoirs of the Queensland Museum 25: 233-237.

Coughran, J. 2013. Biology of the mountain crayfish Euastacus sulcatus Riek, 1951 (Crustacea: Parastacidae) in New South Wales, Australia. Journal of Threatened Taxa 5: 4840-4853. http://dx.doi.org/10.11609/JoTT.o3647.4840-53

Coughran J. and Furse J.M. in press. Conservation of freshwater crayfish in Australia. Crustacean Research.

Cummins, K.W. 1986. Riparian influence on stream ecosystems. Pp. 45-55 in Campbell, I.C. (ed), Stream Protection: The Management of Rivers for Instream Uses. Water Studies Centre, Chisholm Institute of Technology, Melbourne.
Davies, M.M. 2003a. Australian ground frogs (Limnodynastidae). Pp. 139-146 in Duellman, W.E. (ed), Grzimek's Animal Life Encyclopedia, Second Edition, Volume 6. Amphibians. Gale Group, Detroit.

Davies, M.M. 2003b. Australian toadlets and water frogs (Myobatrachidae). Pp. 147-154 in Duellman, W.E. (ed), Grzimek's Animal Life Encyclopedia, Second Edition, Volume 6. Amphibians. Gale Group, Detroit.

Donnellan, S.C., Mahony, M.J. and Davies, M. 1990. A new species of Mixophyes (Anura: Leptodactylidae) and first record of the genus in New Guinea. Herpetologica 46: 266-274.

Donnellan, S.C. and Mahony, M.J. 2004. Allozyme, chromosomal and morphological variability in the Litoria lesueuri species group (Anura: Hylidae), including a description of a new species. Australian Journal of Zoology 52: 1-28. http://dx.doi.org/10.1071/ZO02069

Duellman, W.E. and Trueb, L. 1994. Biology of Amphibians. Johns Hopkins University Press, Baltimore.

Faivovich, J., Haddad, C.F., Garcia, P.C., Frost, D.R., Campbell, J.A., \& Wheeler, W.C. 2005. Systematic review of the frog family Hylidae, with special reference to Hylinae: phylogenetic analysis and taxonomic revision. Bulletin of the American Museum of Natural History 294: 1-240. http://dx.doi. org/10.1206/0003-0090(2005)294\%5B0001:SROTFF\%5D2.0. $\mathrm{CO} ; 2$

Fletcher, J.J. 1889. Observations on the oviposition and habits of certain Australian batrachians. Proceedings of the Linnean Society of New South Wales Series 2 4: 357-387.

Ford, L.S. and Cannatella, D.C. 1993. The major clades of frogs. Herpetological Monographs 7: 94-117. http://dx.doi. org/10.2307/1466954

Frost, D.R., Grant, T., Faivovich, J., Bain, R.H., Haass, A., Haddad, C.F.B., de Sa, R.O., Channing, A., Wilkinson, M., 
Donnellan, S.C., Raxworthy, C.J., Campbell, J.A., Blotto, B.L., Moler, P.L., Drewes, R.C., Nussbaum, R.A., Lynch, J.D., Green, D.M. and Wheeler, W.C. 2006. The amphibian tree of life. Bulletin of the American Museum of Natural History 297: 1-370. http://dx.doi.org/10.1206/0003-0090(2006)297\%5B000 1:TATOL\%5D2.0.CO;2

Furse J.M. 2010. Ecosystem engineering by Euastacus sulcatus (Decapoda: Parastacidae) in the hinterland of the Gold Coast, Queensland, Australia. PhD Thesis. Griffith School of Environment. Griffith University. Gold Coast, Queensland, Australia

Gillespie, G. and Hines, H. 1999. Status of temperate riverine frogs in south-eastern Australia. Pp. 109-130 in Campbell, A. (ed) Declines and Disappearances of Australian Frogs. Environment Australia, Canberra.

Gosner, K.L. 1960. A simplified table for staging anuran embryos and larvae with notes on identification. Herpetologica 16: $183-190$.

Haddad, C.F.B. and Prado C.P.A. 2005. Reproductive modes in frogs and their unexpected diversity in the Atlantic Forest of Brazil. Bioscience 55: 724-724. http://dx.doi.org/10.1641/00063568(2005)055\%5B0207:RMIFAT\%5D2.0.CO;2

Hero, J.-M., Morrison, C., Gillespie, G., Roberts, J.D., Newell, D., Meyer, E., McDonald, K., Lemckert, F., Mahony, M., Osborne, W., Hines, H., Richards, S., Hoskin, C., Clarke, J., Doak, N. and Shoo, L. 2007. Overview of the conservation status of Australian frogs. Pacific Conservation Biology 12: 313-320.

Heyer, R.W. and Leim, D.S. 1976. Analysis of the intergeneric relationships of the Australian frog family Myobatrachidae. Smithsonian Contributions to Zoology 233: 1-29.

Hines, H.B., Mahony, M. and McDonald, K. 1999. An assessment of frog declines in wet subtropical Australia. Pp. 44-63 in Campbell, A. (ed) Declines and Disappearances of Australian Frogs. Environment Australia, Canberra.

Horton, P. 1982. Diversity and systematic significance of anuran tongue musculature. Copeia 1982: 595-602. http:// dx.doi.org/10.2307/1444659

Hoser, R.T. 1989. Australian Reptiles and Frogs. Pierson and Company, Mosman, NSW.

Hoskin, C. and Hero, J.-M. 2008. Rainforest Frogs of the Wet Tropics, Northeast Australia. Griffith University, Gold Coast, Australia.

Hoskin, C.J. 2010. Breeding behaviour of the barred frog Mixophyes coggeri. Memoirs of the Queensland Museum | Nature 55: 1-7.

IUCN 2012. IUCN Red List of Threatened Species. Version 2012.2. <www.iucnredlist.org >. Downloaded on 7 November 2012.

Knowles, R., Hines, H., Thumm, K., Mahony, M. and Cunningham, M. 1998. Oviposition of the barred frogs (Mixophyes species) in southeastern Australia, with implications for management. Abstracts from the 26th Annual General Meeting of the Australian Society of Herpetologists, Yungaburra, Queensland, 1998. (Also available in the Newsletter of the Australian Society of Herpetologists 40 May 2003, p26. http:/ www.australiansocietyofherpetologists.org/pdf/news40.pdf. Accessed 16 Sep 2011)

Lee, M.S.Y. and Jamieson, B.G.M. 1992. The ultrastructure of spermatozoa of three species of myobatrachid frogs (Anura, Amphibia) with phylogenetic considerations. Acta Zoologica 73: 213-222. http://dx.doi.org/10.1111/j.1463-6395.1992.tb01085.x
Lemckert, F. 1999. Impacts of selective logging on frogs in a forested area of northern New South Wales. Biological Conservation 89: 321-328. http://dx.doi.org/10.1016/S00063207(98)00117-7

Lewis, B. 2000. A breeding observation of the stuttering frog (Mixophyes balbus) in northern New South Wales. Herpetofauna 30: 30-33.

Lynch, J.D. 1973. The transition from archaic to advanced frogs. Pp. 133-183 in Vial, J.L. (ed) Evolutionary Biology of Anurans. University of Missouri Press, Columbia.

Magnusson, W.E., \& Hero, J.M. 1991. Predation and the evolution of complex oviposition behaviour in Amazon rainforest frogs. Oecologia 86: 310-318. http://dx.doi.org/10.1007/ BF00317595

Mahony, M., Donnellan, S.C., Richards, S.J. and McDonald, K. 2006. Species boundaries among barred river frogs, Mixophyes (Anura: Myobatrachidae) in north-eastern Australia, with descriptions of two new species. Zootaxa 1228: 35-60.

Mahony, M.J. 1993. The status of frogs in the Watagan Mountains area the central coast of New South Wales. pp. 257264 in Lunney, D. and Ayers, D. (eds) Herpetology in Australia. Surrey Beatty and Sons, Sydney.

Malone, J.H. 2004. Reproduction in three species of Smilisca from Costa Rica. Journal of Herpetology 38:27-35. http://dx.doi. org/10.1670/32-03A

Malone, J.H. 2006. Ecology of the basin construction reproductive mode in Smilisca sordida (Anura: Hylidae). Joumal of Herpetology 40: 230-239. http://dx.doi.org/10.1670/140-05A.1

Marantelli, G. 1995. A captive spawning of the great barred frog, Mixophyes fasciolatus. In the Spotlight - News from the Victorian Frog Group 1:12-13.

Martin, A.A. 1967. Australian anuran life histories: some evolutionary and ecological aspects. Pp. 175-191 in Weatherby, A.H. (ed.) Australian Inland Waters and their Fauna. ANU Press, Canberra, Australia.

Menzies, J.I. 2006. The Frogs of New Guinea and the Solomon Islands. Pensoft, Sofia, Bulgaria

Meyer, E., Hines, H. and Hero, J.-M. 2001. Wet Forest Frogs of South-east Queensland. Griffith University, Brisbane.

Moore, J.A. 1961. The frogs of eastern New South Wales. Bulletin of the American Museum of Natural History 121: 149-386.

Newell, D A., Goldingay, R.L., and Brooks, L.O. 2013. Population recovery following decline in an endangered streambreeding frog (Mixophyes fleayi) from subtropical Australia. PloS One 8: e58559. http://dx.doi.org/10.1371/journal.pone.0058559

O'Reilly, W.K. and Hines, H.B. 2002. Temporal patterns of calling in Fleay's barred frog Mixophyes fleayi at Cunningham's Gap, south-eastern Queensland. Pp. 53-58 in Nattrass, A.E.O. (ed) Frogs in the Community: Proceedings of the Brisbane Symposium 13-14 February 1999. Queensland Frog Society, Brisbane.

Parris, K.M. and Norton, T.W. 1997. The significance of State Forests for conservation of Litoria pearsoniana (Copland) and associated amphibians. Pp. 521-26 in Hale, P. and Lamb, D. (eds) Conservation Outside Nature Reserves. Centre for Conservation Biology, University of Queensland, Brisbane.

Parris, K.M. 2002. The distribution and habitat requirements of the great barred frog (Mixophyes fasciolatus). Wildlife Research 29: 469-474. http://dx.doi.org/10.1071/WR01107

Pusey, B.J., Kennard, M.J., and Arthington, A.H. 2004. Freshwater fishes of north-eastern Australia. CSIRO Publishing, Collingwood, Australia. 
Pusey, B.J. and Arthington, A.H. 2003. Importance of the riparian zone to the conservation and management of freshwater fish: a review. Marine and Freshwater Research 54: 1-16.

Pyron, R.A. 2014. Biogeographic analysis reveals ancient continental vicariance and recent oceanic dispersal in amphibians. Systematic Biology 63: 779-797. http://dx.doi. org/10.1093/sysbio/syu042

Pyron, R.A. and Wiens, J.J. 2001. A large scale phylogeny of Amphibia including over 2800 species and a revised classification of extant frogs, salamanders and caecilians. Molecular Phylogenetics and Evolution. 61: 543-583.

Resetarits, W.J. 1996. Oviposition site choice and life history evolution. American Zoologist, 36: 205-215.

Richards, S.J. and Alford, R.A. 1992. Nest construction by an Australian rainforest frog of the Litoria lesueuri complex (Anura: Hylidae). Copeia 1992: 1120-1123. http://dx.doi. org/10.2307/1446653

Richards, S.J. 1993. Functional significance of nest construction by an Australian rainforest frog: a preliminary analysis. Memoirs of the Queensland Museum 34: 89-93.

Robinson, M. 1993. A Field Guide to Frogs of Australia. Reed, Chatswood, NSW.

Roelants, K., Gower, D.J., Wilkinson, M., Loader, S.P., Biju, S.D., Guillaume, K., Moriau, L. and Bossuyt, F. 2007. Global patterns of diversification in the history of modern amphibians. Proceedings of the National Academy of Sciences 104: 887-892. http://dx.doi.org/10.1073/pnas.0608378104

Seymour, R.S., Mahony, M.J. and Knowles, R. 1995. Respiration of embryos and larvae of the terrestrially breeding frog Kyarranus loveridgei. Herpetologica 51: 369-376.
Stratford, D.S., Grigg, G.C., McCallum, H.I. and Hines, H.B. 2010. Breeding ecology and phenology of two stream breeding myobatrachid frogs (Mixophyes fleayi and M. fasciolatus) in southeast Queensland. Australian Zoologist 35: 189-197. http://dx.doi. org/10.7882/AZ.2010.007

Straughan, I.R. 1966. An analysis of species recognition and species isolation in certain Queensland frogs. PhD Thesis, University of Queensland.

Straughan, I.R. 1968. A taxonomic review of the genus Mixophyes, (Anura, Leptodactylidae). Proceedings of the Linnean Society of New South Wales 93: 52-59.

Stuart, N., Hoffmann, M., Chanson, J.S., Cox, N.A., Berridge, R.J., Ramani, P. and Young, B.E. 2008. Threatened Amphibians of the World. Lynx Edicions, Barcelona, Spain.

Treadwell, S., Koehn, J., and Bunn, S. 1999. Large woody debris and other aquatic habitat. Pp. 79-96 in Lovett, S., and Price, P. (eds) Riparian Land Management Technical Guidelines Volume One: Principles of Sound Management. Land and Water Resources Research and Development Corporation, Canberra.

Tyler, M.J. 1985. Reproductive modes in Australian Amphibia. Pp. 265-267 in Grigg, G.C. and Shine, R. (eds) Biology of Australasian Frogs and Reptiles Surrey Beatty in association with The Royal Zoological Society of New South Wales, Chipping Norton, NSW.

Tyler, M.J. 1994. Australian Frogs. A Natural History. Reed Books, Chatswood, NSW.

Watson, G.F. and Martin, A.A. 1973. Life history, larval morphology and relationships of Australian leptodactylid frogs. Transactions of the Royal Society of South Australia 97: 33-45.

Wells, K.D. 2007. The Ecology and Behaviour of Amphibians. University of Chicago Press, Chicago, USA. 